IZA DP No. 6262

Are Drone Strikes Effective in Afghanistan and Pakistan? On the Dynamics of Violence between the United States and the Taliban

David A. Jaeger

Zahra Siddique

December 2011 


\title{
Are Drone Strikes Effective in Afghanistan and Pakistan? On the Dynamics of Violence between the United States and the Taliban
}

\author{
David A. Jaeger \\ CUNY Graduate Center
}

\section{Zahra Siddique}

IZA

\author{
Discussion Paper No. 6262
}

December 2011

\author{
IZA \\ P.O. Box 7240 \\ 53072 Bonn \\ Germany \\ Phone: +49-228-3894-0 \\ Fax: +49-228-3894-180 \\ E-mail: iza@iza.org
}

\begin{abstract}
Any opinions expressed here are those of the author(s) and not those of IZA. Research published in this series may include views on policy, but the institute itself takes no institutional policy positions.

The Institute for the Study of Labor (IZA) in Bonn is a local and virtual international research center and a place of communication between science, politics and business. IZA is an independent nonprofit organization supported by Deutsche Post Foundation. The center is associated with the University of Bonn and offers a stimulating research environment through its international network, workshops and conferences, data service, project support, research visits and doctoral program. IZA engages in (i) original and internationally competitive research in all fields of labor economics, (ii) development of policy concepts, and (iii) dissemination of research results and concepts to the interested public.
\end{abstract}

IZA Discussion Papers often represent preliminary work and are circulated to encourage discussion. Citation of such a paper should account for its provisional character. A revised version may be available directly from the author. 


\section{ABSTRACT \\ Are Drone Strikes Effective in Afghanistan and Pakistan? On the Dynamics of Violence between the United States and the Taliban*}

Strikes by unmanned aerial vehicles, or drones, have been the primary weapon used by the United States to combat the Taliban and Al-Qaeda in Afghanistan and Pakistan. This paper examines the dynamics of violence involving drone strikes and the Taliban/Al-Qaeda in Afghanistan and Pakistan from January 2007 to December 2010. We find that drone strikes do not have any significant impact on terrorist violence in Afghanistan but that drone strikes do have a significant impact on Taliban/Al-Qaeda violence in Pakistan. We find that our results are robust to examining different time periods and lag structures. We also examine the impact of successful and unsuccessful drone strikes (which did or did not succeed in targeted killing of a militant leader) on terrorist attacks by the Taliban. We find strong negative impacts of unsuccessful drone strikes on Taliban violence in Pakistan, showing the deterrent effects are quite strong, while the incapacitation effects appear to be weak or nonexistent.

JEL Classification: C32, D74

Keywords: $\quad$ time series models, conflict

Corresponding author:

Zahra Siddique

IZA

P.O. Box 7240

53072 Bonn

Germany

E-mail: siddique@iza.org

\footnotetext{
* We thank seminar participants at IZA for helpful comments. Zahra Siddique thanks the Development Policy Research Center at the Lahore University of Management Sciences for support during a research visit in Summer 2011.
} 
Attacks by unmanned aerial vehicles, or drones, have been one of the main policies used by the United States to carry out targeted killings of terrorists in Afghanistan and Pakistan. The perceived success of these attacks has led to a substantial increase in the use of drones as a strategic tool of the U.S. Central Intelligence Agency and its military around the globe. ${ }^{1}$ In Afghanistan and Pakistan, the targets are typically Taliban and Al-Qaeda militant leaders in the Federally Administered Tribal Areas (FATA) of Northwest Pakistan. And although drone strikes have killed important Taliban leaders, their use is unpopular in Pakistan due to the "collateral" civilian casualties often associated with them, as well as possible retaliation against civilians by the Taliban. For example, in a terrorist attack on a police academy in Lahore in March 2009 in which eighteen people were killed, Baitullah Mehsud (then leader of the Tehrik-e-Taliban Pakistan) stated that the attack was "in retaliation for the continued drone strikes by the United States in collaboration with Pakistan on our people." 2

While the primary strategic goal of U.S. drone strikes in the FATA is to incapacitate the Al-Qaeda and eliminate its capacity to attack the U.S., subsidiary goals must also be to reduce terrorist attacks by the Taliban and Al-Qaeda against U.S. and NATO forces in Afghanistan and to assure security of Pakistan's nuclear weapons. Thus, long-run chances of success for the U.S. and its allies in the region are surely diminished by continued reprisal terrorist attacks by the Taliban and Al-Qaeda against Pakistanis and Afghanis. This paper examines the extent to which drone strikes affect subsequent violence by the Taliban and Al-Qaeda - in particular, whether the number and incidence of terrorist attacks increases (through in retaliation and reprisal) or decreases (due to incapacitation and deterrence). Following Jaeger and Paserman's $(2006,2008,2009)$ work on the Second Intifada in Israel, we exploit daily variation in drone strikes and terrorist attacks by the Taliban and Al-Qaeda in Afghanistan and Pakistan from January 2007 to December 2010 to estimate vector autoregressions of the dynamic patterns of violence. We also empirically test the hypothesis of whether there is co-ordination in Taliban violence across the border in Afghanistan and Pakistan. ${ }^{3}$

We contribute to the literatures on counterterrorism measures and asymmetric conflict by examining the efficacy of U.S. counter-terrorism policy (drone strikes) to combat the Taliban and Al-Qaeda, and examine whether the use drone strikes affects terrorist actions in Afghanistan, where the US is directly

\footnotetext{
1 Washington Post, 28 December 2011, "Under Obama, An Emerging Global Apparatus for Drone Killing," http://www . washingtonpost.com/national/national-security/under-obama-an-emerging-global-apparatus-for-drone-killing/ 2011/12/13/gIQANPdILP_story.html, last accessed 28 December 2011.

${ }^{2}$ BBC, 31 March 2009, "Lahore 'was Pakistan Taleban op'," http://news.bbc.co.uk/2/hi/south_asia/7973540.stm, last accessed 28 December 2011.

${ }^{3}$ The Taliban are comprised of Pashtun tribes located in the border areas of Afghanistan (south and south east areas) and Pakistan (north and north west areas). While there are different factions within the Taliban, a general perception is that there is co-ordination in Taliban violence across the two countries.
} 
engaged with the Taliban, and in Pakistan, where, except for the FATA, the U.S. is not directly engaged with the Taliban. We find that there is no significant impact of drone strikes on Taliban and Al-Qaeda attacks in Afghanistan but that there is a significant impact of drone strikes on Taliban and Al-Qaeda attacks in Pakistan. This impact varies from a positive vengeance effect in the first week following a drone strike to a negative deterrent/incapacitation effect in the second week following a drone strike, when we examine the likelihood of a terrorist attack by the Taliban. The impact is negative in both the first and second weeks following a drone strike, when we examine the number of terrorist attacks by the Taliban. We find that drone strikes continue to have a strong impact on terrorist attacks by the Taliban and Al-Qaeda in Pakistan when we look at different time periods or lag structures.

In Section 1 of the paper we describe the background of the conflict involving the Taliban and Al-Qaeda and in Section 2 we describeour data sources. Section 3 presents our econometric approach and Section 4 gives the baseline estimation results. In Section 5 we perform some robustness checks on the baseline estimation results and in Section 6 we present some extensions regarding successful and unsuccesful drone strikes as well as actions by specific terrorist actors. Section 7 concludes.

\section{Background}

The Taliban consist of ethnic Pashtun tribes found along the border areas of Afghanistan and Pakistan. While the Taliban in Afghanistan are a fairly monolithic group, in Pakistan there are currently several militant groups which are collectively referred to as Taliban. The most important of these is the Tehrik-eTaliban Pakistan which acts as an umbrella movement for various commanders across the South Waziristan agency of the Federally Administered Tribal Areas (FATA). The Tehrik-e-Taliban Pakistan has been particularly active in carrying out terrorist attacks within Pakistan. Another important faction is the Haqqani faction which operates in the North Waziristan agency of FATA and is more actively involved in terrorist attacks in Afghanistan. The different militant groups share resources, expertise, and training with each other, with Al Qaeda playing an important role by networking between the different local militant factions.

While Pakistan's official support for the Taliban ended after September 2001 the Pakistan military did not enter the FATA till July 2002. This was also the first time that the Pakistan government had directly interfered in these areas since gaining independence in 1947. In June 2004 the first drone strike in the region was reported by the media. Between 2004 and 2005, the Pakistan military engaged with the Taliban and suffered heavy casualties in the northern areas. In September 2006 Pakistan signed the 
Waziristan accord, a peace deal to end all fighting with the Taliban. The Waziristan Accord was officially at an end in July 2007 when the Pakistan military laid siege to the Red Mosque (Lal Masjid) in the capital city of Islamabad in which Islamic militants were holed up. Since the Red Mosque siege, there has been a sharp escalation in terrorist attacks by the Taliban across Pakistan. During this time the number of drone strikes by the US targeting the Taliban leadership continued. Between February and April 2009 there was another peace agreement between the Taliban and Pakistan, also known as the Malakand Accord. In August 2009 a drone strike succeeded in killing Baitullah Mehsud, the leader of the Tehrik-e-Taliban Pakistan, who was succeeded by Hakimullah Mehsud. During 2008 and 2009, the Pakistan military was also involved in four major offenses against the Taliban: from January to May 2008, September to October 2008, May 2009 and October to December 2009.

\section{Data}

We use the Worldwide Incidents Tracking System (WITS) database collected by the National Counter Terrorism Center as our source of terrorist incidents in Afghanistan and Pakistan from January 2007 to December 2010, where the perpetrators were identified in the database as Taliban. ${ }^{4}$ As a robustness check we examine whether the incidents reported by the WITS database are consistent with other databases on terrorist incidents such as the Global Terrorism Database maintained by the National Consortium for the Study of Terrorism and Responses to Terrorism at the University of Maryland and the RAND Database of Worldwide Terrorism Incidents. ${ }^{5}$ While we do not find a perfect correlation in the number of terrorist attacks carried out by the Taliban in the different databases, we did find the WITS database to have the best coverage of such incidents. For instance, we found an almost perfect correlation between the suicide attacks attributed to the Taliban in WITS with a proprietary administrative data source which documented such attacks, while the other databases entirely miss large numbers of such incidents.

Incidents in the WITS database consist of all "incidents in which sub-national or clandestine groups or individuals deliberately or recklessly attacked civilians or noncombatants (including military personnel and assets outside war zones and war like settings)." An important consideration concerns what constitutes a "terrorist act." To be included in the WITS database terrorists must have initiated and executed the attack, with spontaneous hate crimes and genocides being excluded from the database. A potential

\footnotetext{
${ }^{4}$ See https://wits.nctc.gov/.

${ }^{5}$ The Global Terrorism Database is available at http://www.start.umd.edu/gtd/ and the RAND data are available at http://www.rand.org/nsrd/projects/terrorism-incidents.html.
} 
problem in using the database is that it is sometimes difficult to separate crime from terrorist act. In general, a crime committed in support of terrorism is included in the database, but not otherwise.

Data on incidence and fatalities arising from drone strikes comes from the New America Foundation, which collects and provides data on incidence, day, location, fatalities (including those of militant leaders), intended target and source of information. ${ }^{6}$ The sources from which the data is compiled include media organizations such as the New York Times, Washington Post and Wall Street Journal, news services and networks such as the Associated Press, Reuters, Agence France-Presse, CNN and BBC, English language media from Pakistan such as the Daily Times, Dawn and the News and GEO TV.

In Table 1 we show the frequency of drone strikes by the U.S. and terrorist attacks by the Taliban and Al-Qaeda from 2005 to 2010. It is clear that there is an increase in both drone strikes and overall terrorist attacks in this period, although the share of terrorist attacks occurring in Pakistan has declined. The success rate of drone strikes has declined substantially, as has the share of suicide attacks in terrorist actions.

We present this information at a higher frequency in Figure 1, which shows the monthly number of terrorist attacks by the Taliban and Al-Qaeda in Afghanistan and Pakistan, as well as the monthly number of drone strikes. Vertical lines indicate important time periods of the conflict: the Red Mosque siege of July 2007 in Pakistan, the start of the Obama administration in office from February 2009, the Malakand accord from February to April 2009 and the four different military campaigns by the Pakistan military against the insurgents. The frequency of terrorist attacks by the Taliban in Pakistan clearly increased after the Red Mosque siege in 2007. There were large numbers of attacks in 2008 and 2009 but fewer in 2010, after the August 2009 killing of a a key leader of the Taliban in Pakistan, Baitullah Mehsud, in a drone strike. In Afghanistan, the number of terrorist attacks by the Taliban is about twice as high as in Pakistan and has increased over time. Note that there is seasonal variation in the terrorist attacks by the Taliban in Afghanistan with the highest number of attacks occurring during the summer months. Drone strikes are fewer in number but their use has increased since the start of 2008 , and particularly gone up during 2010. There is a definite increase in the number of drone strikes since the Obama administration took office in 2009.

In Figure 2 we show the spatial distribution of the aggregate number of terrorist attacks by the Taliban and Al-Qaeda in Afghanistan across its thirty five states between January 2007 and December 2010. From the map, the geographical concentration of terrorist attacks is, not surprisingly, in areas dominated by

\footnotetext{
${ }^{6}$ See http://counterterrorism.newamerica.net/drones.
} 
the Taliban in the south and south east of Afghanistan. Similarly, Figure 3 gives the spatial distribution of the aggregate number of terrorist attacks in Pakistan across its four states between January 2007 and December 2010. From this, it can be seen that most of the terrorist attacks are geographically concentrated in the north and north west of the country, close to the FATA where the drone strikes take place.

Because Al-Qaeda has directly claimed responsibility for a very small number of terrorist attacks (4 in Afghanistan and 9 in Pakistan in our sample period), in the rest of the paper we will refer to the "Taliban" as the terrorist actor in the analysis.

\section{$3 \quad$ Framework and Econometric Strategy}

To examine the effects of drone strikes on Taliban violence in Afghanistan and Pakistan, we posit a simple vector autoregressive model similar to that of Jaeger and Paserman (2008). We are particularly interested in whether drone strikes reduce subsequent Taliban violence For the Taliban in Afghanistan, we estimate reaction functions of the form

$$
T_{t}^{A}=f_{i}\left(D_{t-1}, \ldots, D_{t-p}, T_{t-1}^{P}, \ldots, T_{t-p}^{P}, T_{t-1}^{A}, \ldots, T_{t-p}^{A}, X_{t}\right)
$$

and in Pakistan,

$$
T_{t}^{P}=f_{i}\left(D_{t-1}, \ldots, D_{t-p}, T_{t-1}^{A}, \ldots, T_{t-p}^{A}, T_{t-1}^{P}, \ldots, T_{t-p}^{P}, X_{t}\right)
$$

where $T_{t}^{A}, T_{t}^{P}$ and $D_{t}$ represent period $t$ terrorist attacks by the Taliban in Afghanistan, terrorist attacks by the Taliban in Pakistan and drone strikes, respectively, $p$ is the maximum number of lags that have a non-zero effect and $X_{t}$ is a vector of variables that may shift the reaction function up or down or change the parameters of the reaction function. For the sake of symmetry we also estimate and report the reaction functions for the United States government in its exercise of drone strikes in the FATA:

$$
D_{t}=f_{i}\left(T_{t-1}^{A}, \ldots, T_{t-p}^{A}, T_{t-1}^{P}, \ldots, T_{t-p}^{P}, D_{t-1}, \ldots, D_{t-p}, X_{t}\right) .
$$

Note, however, that it is unlikely (as we also find in the data) that drone strikes are strategically affected by the incidence and intensity of terrorist attacks by the Taliban in either Afghanistan or Pakistan, and more likely based on intelligence gathered on high value Taliban and terrorist targets. To the extent that this intelligence gathering (and the timing of drone strikes) is independent the unobserved determinants 
of Taliban actions, our estimates of these parameters in the Taliban reaction functions can be viewed the causal effects of drone strikes on Taliban actions (Granger 1969).

In both of the Taliban equations, we pay particular attention to the signs of the coefficients. We hypothesize that drone strikes can lead to subsequent reductions in terrorist activity if they incapacitate the Taliban or deter the Taliban from further violence. On the other hand, drone strikes may induce further violence through vengeance. If the coefficients on the $D_{t-1}, \ldots, D_{t-p}$ variables are negative, then the incapacitation and deterrence effects dominate (on net) while if they are positive then the vengeance effect dominates (on net). We also estimate a specification (in section 6) in which we separate successful drone strikes (ones which killed a militant leader) from those which were not successful (one which did not kill a militant leader). We expect the coefficients associated with successful drone strikes to capture the incapacitation, deterrence and vengeance effects while the coefficients associated with unsuccessful drone strikes potentially capture the deterrence and vengeance effects only, provided of course that unsuccessful drone strikes do not have any impact on the operational capabilities of the Taliban. Our empirical strategy also allows us to test whether there is any co-ordination in Taliban violence across the border in Afghanistan and Pakistan by exploiting geographic variation in drone strikes, and examine whether drone strikes in Pakistan affect terrorism in Afghanistan and whether drone strikes in Afghanistan affect terrorism in Pakistan.

\section{Baseline Estimation Results}

We estimate the reaction functions (as defined in Section 3) by estimating OLS regressions where we correct for both heteroscedasticity and autocorrelation in the error terms using Newey-West standard errors. We choose a lag length of twenty one days in our baseline estimation, where the choice of lag length is based on likelihood ratio tests that we carried out on the initial estimations. We estimate two different specifications: in the first specification (which we refer to as the incidence specification), $T_{t}^{A}, T_{t}^{P}$ and $D_{t}$ are dummy variables for whether there was any terrorist attack by the Taliban in Afghanistan, by the Taliban in Pakistan or whether there was any drone strike on day $t$. In the second specification (which we refer to as the levels specification), $T_{t}^{A}, T_{t}^{P}$ and $D_{t}$ are the number of terrorist attacks by the Taliban in Afghanistan, by the Taliban in Pakistan and the number of drone strikes on day $t$.

All regressions include day of week indicators and a series of indicators variables to control for different periods in the conflict: a) a dummy variable that takes the value one after the Red Mosque siege of fourth July 2007, b) a dummy variable which takes the value one for after the Obama administration took office 
from twenty first January 2009, c) a dummy variable which takes the value one during the time of the Malakand accord from fifteenth February to thirteenth April 2009 and d) dummy variables for each of four military campaigns undertaken by the Pakistan military against the insurgents. ${ }^{7}$

Table 2 gives the estimation results of the drone strikes reaction functions. The second column in the table gives the estimation results from the incidence specification while the fourth gives estimation results from the levels specification. We find that a drone strike is $5.2 \%$ more likely to occur fourteen days after a terrorist attack by the Taliban in Afghanistan and $4.4 \%$ more likely to occur nine days after a terrorist attack by the Taliban in Pakistan and these increases are statistically significant at the $2.5 \%$ level of significance. There are 0.010 fewer drone strikes fifteen days after one terrorist attack by the Taliban in Afghanistan. There are 0.040 fewer drone strikes four days after one terrorist attack by the Taliban in Pakistan (everything else constant) and 0.028 fewer drone strikes eighteen days after one terrorist attack by the Taliban in Pakistan (everything else constant). These declines are statistically significant at the $2.5 \%$ level of significance. At the same time, there are 0.013 more drone strikes eighteen days after one terrorist attack by the Taliban in Afghanistan (everything else constant) and 0.025 more drone strikes nine days after one terrorist attack by the Taliban in Pakistan (everything else constant). We do not find that the all coefficients on lags of terrorist attacks by the Taliban in Afghanistan or all coefficients on lags of terrorist attacks by the Taliban in Pakistan to be jointly significantly different from zero in the incidence specification. We do find that all coefficients on lags of terrorist attacks by the Taliban in Afghanistan and all coefficients on lags of terrorist attacks by the Taliban in Pakistan are jointly significantly different from zero in the levels specification.

Table 3 gives the estimation results of the reaction functions of the Taliban in Afghanistan. The second column gives the estimation results when using the incidence specification while the fourth column gives the coefficients when using the levels specification. These reaction functions give two important results: first there is some evidence that more terrorist attacks by the Taliban in Pakistan reduce terrorist attacks by the Taliban in Afghanistan and second that drone strikes have no impact on terrorist attacks by the Taliban in Afghanistan. From Table 3 we find that terrorist attacks in Afghanistan are $5.4 \%$ less likely to occur eight days after a terrorist attack by the Taliban in Pakistan and this decrease is statistically significant at the $1 \%$ level. There is no significant impact of drone strikes on terrorist attacks by the Taliban in Afghanistan, and we do not find that the coefficients on all lags of drone strikes or coefficients on all lags of terrorist attacks by the Taliban in Pakistan in the incidence specification are

\footnotetext{
${ }^{7}$ These military campaigns occur from first January to thirty first May 2008, from twenty third September to thirty first October 2008, from first to thirty first May 2009 and from eighteenth October to twelfth December 2009.
} 
jointly significantly different from zero. We do find that coefficients on all lags of terrorist attacks by the Taliban in Pakistan in the levels specification are jointly significantly different from zero, indicating that there is likely to be some coordination between the Taliban groups in the two countries.

Table 4 gives the estimation results of the reaction functions of the Taliban in Pakistan, structured in the same was as in Table 2. We find strong effects of drone strikes on subsequent Taliban violence in Pakistan, although the sign of these effects are somewhat mixed. We find that a terrorist attack by the Taliban in Pakistan is $8.2 \%$ more likely to occur five days after a drone strike but $8.9 \%$ less likely to occur thirteen days after a drone strike and these effects are statistically significant at the $2.5 \%$ level of significance. There are also 0.120 fewer terrorist attacks two days after a drone strike and 0.130 fewer terrorist attacks twelve days after a drone strike. These effects are significant at the $1 \%$ level. When we test for joint significance of all lags of drone strikes on terrorist attacks by the Taliban in Pakistan we find that these lags are jointly significant in explaining such attacks in both the incidence and levels specifications. We also find that Taliban violence in Pakistan is negatively associated with Taliban violence in Afghanistan; a terrorist attack is 9.3\% less likely to occur sixteen days after a terrorist attack in Afghanistan and 0.023 fewer terrorist attacks occur sixteen days after one terrorist attack in Afghanistan. In a test of joint significance of all lags of terrorist attacks in Afghanistan we find these lags to be jointly significant in the levels specification but not in the incidence specification.

We next carry out a number of robustness checks to determine whether these baseline results persist when we when we vary the lag structure, the level of aggregation, and focus on lethal Taliban attacks. ${ }^{8}$

\section{Robustness Checks}

\subsection{Lag Structures}

It is possible that the baseline Granger-causality results that we reported are dependent on the lag length that we chose in the estimation of our reaction functions. We chose the lag length based on likelihood ratio statistics. To check the robustness of our results, however, we also examine whether choosing a different lag length would change our results. In Table 5, we present results using lags of seven and fourteen days. Overall, we find little change by estimating models with $p=7$ or $p=14$.

\footnotetext{
${ }^{8}$ In results available from the authors by request, we have also estimated the baseline specifications only for the 2008-2010 period, when drone strikes began to be used in significant numbers, as well as the period after the Red Mosque Siege in July 2007, which was a triggering event for elevated terrorist activity. The results are qualitatively similar to those presented in Tables 2 through 4.
} 


\subsection{Time Aggregation}

In our baseline specification, we examined the short-run (3 week) dynamics of violence and found that there is little effect of drone strikes on Taliban actions in Afghanistan and a significant, but somewhat mixed, effect on Taliban actions in Pakistan. Unlike the Palestinians in Israel we expect that the Taliban has somewhat greater ability to act in Afghanistan, in particular. But it may be that using high-frequency data masks some longer-term reaction (or deterrence) of Taliban actions. To explore this issue, we estimate models similar to those in Tables 2 through 4, but using weekly and monthly aggregation of the data. Here we find some differences with our baseline specification. In particular, we find no significant effects of drone strikes on Taliban violence in Pakistan when we aggregate to weeks or months. At the monthly frequency, we do find a significant effect of drone strikes on Taliban violence in Afghanistan. In this regression, the coefficient on drone strikes is negatively and highly significant - indicating that drone strikes may have a deterrence or incapacitation effect on longer-run violence in Afghanistan.

\subsection{Outcome Measure}

We have thus far measured intensity of Taliban actions only by using the incidence or number of terrorist attacks. To explore this issue further, we now look at two somewhat different outcomes by examining either those Taliban actions that resulted in at least one fatality as well as only those in which a suicide attack occurred. We use data on incident description and fatalities in WITS to construct the incidence and number of lethal and suicide terrorist attacks by the Taliban in Afghanistan and in Pakistan.

The tests of joint significance are reported in table 7 . The effect of drone strikes on both lethal and suicide attacks in Afghanistan is similar to the baseline specification - there is no effect on either incidence or levels. The results in Pakistan are somewhat more mixed, where we find that drone strikes have a jointly significant (at the $5 \%$ level) effect on lethal attacks, but no significant effect on either the incidence or level of suicide attacks there. This is consistent with the evidence from the Palestinian-Israeli conflict, where Jaeger and Paserman (2009) found that Israeli counter-terrorism measures had little predictive power for suicide attacks, perhaps because suicide attacks take longer to organize than other types of violence and require elements of surprise in order to be effective. 


\section{$6 \quad$ Extensions}

\subsection{Haqqani and Mehsud Factions of the Taliban}

So far we have considered the Taliban to be a monolithic group, with the only distinction being in terrorist attacks carried out across the border in either Afghanistan or Pakistan. Two distinct factions within the Taliban have been targeted by drone strikes in recent years, however, and these factions have a base of operations in different parts of the FATA. The Haqqani faction of the Taliban is based in North Waziristan while the Tehrik-e-Taliban Pakistan (thereafter referred to as the Mehsud faction of the Taliban) is based in South Waziristan areas of FATA. Drone strikes carried out in North Waziristan target the Haqqani faction while drone strikes in South Waziristan target the Mehsud faction. The Haqqani faction of the Taliban is believed to carry out terrorist attacks in parts of Afghanistan while the Mehsud faction is believed to carry out terrorist attacks in the FATA areas of Pakistan. We estimate reaction functions for each faction by using geographical information on terrorist attacks and drone strikes. We estimate the reaction function for the Haqqani faction of the Taliban by using data on terrorist attacks by the Taliban in parts of Afghanistan which are believed to be the Haqqani areas of combat operations; these include the eastern states of Khost, Paktia, Paktika, Ghazni, Logar, Wardak, and Kabul in Afghanistan. We estimate reaction functions for the Mehsud faction of the Taliban by using data on terrorist attacks by the Taliban in the FATA areas of Pakistan which are believed to be the Mehsud areas of combat operations.

For the Haqqani faction of the Taliban the reaction functions we estimate are of the form

$$
T_{t}^{\text {Haqqani }}=f_{i}\left(D_{t-1}^{\text {Haqqani }}, \ldots, D_{t-p}^{\text {Haqqani }}, T_{t-1}^{\text {Haqqani }}, \ldots, T_{t-p}^{\text {Haqqani }}, X_{t}\right)
$$

where $T_{t}^{\text {Haqqani }}$ represents terrorist attacks by the Taliban in the eastern states of Khost, Paktia, Paktika,

Ghazni, Logar, Wardak, and Kabul in Afghanistan at time $t$ and $D_{t}^{\text {Haqqani }}$ represents drone strikes in North Waziristan at time $t$. As above, $p$ is the maximum number of lags that have a non-zero effect and $X_{t}$ is a vector of variables that may shift the reaction function up or down or change the parameters of the reaction function.

Our empirical strategy is similar to before, with estimation of empirical reaction functions by OLS with twenty-one lags and Newey-West standard errors. The estimation results are reported in table 8 , with the second column giving the estimation results from the incidence specification and the fourth column giving the estimation results from the levels specification. A terrorist attack in the Haqqani areas in eastern Afghanistan is $14.1 \%$ more likely to occur eight days after a drone strike in North Waziristan, indicating 
the vengeance effect dominates the incapacitation/deterrence effect. At the same time there are 0.183 fewer terrorist attacks two days after one drone strike in North Waziristan, ceteris paribus and 0.213 more terrorist attacks nine days after one drone strike in North Waziristan (everything else constant). Overall, there appear to be short-term deterrent/incapacitation effect of drone strikes in the first week but large vengeance effects in the second week following a drone strike for the Haqqani faction of the Taliban.

For the Mehsud faction of the Taliban the reaction functions we estimate are of the form

$$
T_{t}^{M e h s u d}=f_{i}\left(D_{t-1}^{M e h s u d}, \ldots, D_{t-p}^{M e h s u d}, T_{t-1}^{M e h s u d}, \ldots, T_{t-p}^{M e h s u d}, X_{t}\right)
$$

where $T_{t}^{\text {Mehsud }}$ represents terrorist attacks by the Taliban in the FATA areas of Pakistan at time $t$ and $D_{t}^{\text {Mehsud }}$ represents drone strikes in South Waziristan at time $t . p$ is the maximum number of lags that have a non-zero effect and $X_{t}$ is a vector of variables that may shift the reaction function up or down or change the parameters of the reaction function.

The estimation results are reported in table 9, with the second column giving the estimation results from the incidence specification and the fourth column giving the estimation results from the levels specification. We find that a terrorist attack in FATA is $17.3 \%$ more likely eleven days after a drone strike in South Waziristan but that it is $14.1 \%$ less likely fourteen days after a drone strike in South Waziristan. There are also 0.142 more terrorist attacks fourteen days after a drone strike (everything else constant). Overall there appear to be vengeance effects but also large deterrent/incapacitation effects occurring in the second week after a drone strikes for the Mehsud faction of the Taliban.

\subsection{Successful and Unsuccessful Drone Strikes}

Jaeger and Paserman (2009) found differential effects of successful and unsuccessful assassination attempts of Palestinian leaders. We employ a similar strategy here by exploiting information on whether or not a particular drone strike was successful in eliminating a militant leader. By decomposing the drone strikes into those which were successful and not successful, we are able to investigate the individual deterrence and incapacitation effects of drone strikes on terrorist violence.

For the Taliban in Afghanistan the reaction functions we estimate are of the form,

$$
T_{t}^{A}=f_{i}\left(D_{t-1}^{S}, \ldots, D_{t-p}^{S}, D_{t-1}^{U}, \ldots, D_{t-p}^{U}, T_{t-1}^{P}, \ldots, T_{t-p}^{\text {Pakistan }}, T_{t-1}^{A}, \ldots, T_{t-p}^{A}, X_{t}\right)
$$


where $D_{t}^{S}$ and $D_{t}^{U}$ represent drone strikes which were successful and which were not successful in killing a militant leader at time $t$, respectively. $p$ is The estimation results are reported in table 10 , with the second column giving the estimation results from the incidence specification and the fourth column giving the estimation results from the levels specification. We find that there is no large and significant impact of unsuccessful drone strikes on terrorist attacks by the Taliban in Afghanistan, but a terrorist attack in Afghanistan is $8.8 \%$ more likely five days after a successful drone strike. This indicates that vengeance effects may be particularly strong when drone strikes are able to kill militant leaders for Taliban violence in Afghanistan.

For the Taliban in Pakistan the reaction functions we estimate are of the form,

$$
T_{t}^{P}=f_{i}\left(D_{t-1}^{S}, \ldots, D_{t-p}^{S}, D_{t-1}^{U}, \ldots, D_{t-p}^{U}, T_{t-1}^{A}, \ldots, T_{t-p}^{A}, T_{t-1}^{P}, \ldots, T_{t-p}^{P}, X_{t}\right)
$$

with the variables defined as above. The estimation results are reported in table 11, with the second column giving the estimation results from the incidence specification and the fourth column giving the estimation results from the levels specification. We find that a terrorist attack in Pakistan is $17.8 \%$ less likely to occur three days after a successful drone strike, but also that a terrorist attack in Pakistan is $13 \%$ less likely to occur twelve days after an unsuccessful drone strike and that there are 0.151 fewer terrorist attacks in Pakistan eleven days after one unsuccessful drone strike (all else constant). These effects are statistically significant. Note, however, that the magnitude of all the coefficients is not very different across successful and unsuccessful drone strikes. It appears that there is little incapacitation effect of the Taliban due to a lost militant leader. On the other hand, strong negative effects associated with unsuccessful drone strikes indicate a potential effect of drone strikes for Taliban violence in Pakistan. This is also consistent with conventional wisdom, while the drone strikes may do little to damage the operational capabilities of the Taliban (there are always other Taliban recruits to take the place of a militant leader killed in a drone strike), but the show of strength through these strikes may reduce subsequent terrorist attacks by the Taliban in Pakistan.

\section{Conclusion}

We examine the dynamics of the conflict involving the Taliban across Afghanistan and Pakistan and the use of drone strikes as a counter-terrorism policy to combat the Taliban. We test the following hypotheses: do the Taliban increase or decrease terrorist attacks following drone strikes which target militant leaders 
of the Taliban? How do the impacts differ across the border in attacks carried out by the Taliban in Afghanistan and attacks carried out by the Taliban in Pakistan? Is there a cycle of violence associated with the use of drone strikes by the United States government in Pakistan? Does U.S. policy to combat the Taliban and Al-Qaeda (in the form of drone strikes) have some impact on terrorist activities of the Taliban in neighboring Afghanistan?

We find that there is little significant impact of drone strikes on Taliban attacks in Afghanistan but that there is a significant impact of drone strikes on Taliban attacks in Pakistan. This impact varies from a positive vengeance effect in the first week following a drone strike to a negative deterrent/incapacitation effect in the second week following a drone strike, when we examine the incidence of terrorist attacks by the Taliban. The impact is negative in both the first and second week following a drone strike, when we examine the number of terrorist attacks by the Taliban.

We also examine whether drone strikes in North Waziristan have an impact on Taliban violence in parts of Afghanistan under the control of the Haqqani faction of the Taliban. We examine whether drone strikes in South Waziristan have an impact on Taliban violence in the Federally Administered Tribal Areas under the control of the Mehsud faction of the Taliban. We find some vengeance effects of drone strikes on violence by the Haqqani faction but also deterrent/incapacitation effects of drone strikes on violence by both the Haqqani and Mehsud factions of the Taliban. We estimate the differential effects of successful and unsuccessful drone strikes (which kill and do not kill a militant leader) on Taliban violence in Afghanistan and in Pakistan. We find strong negative impacts of unsuccessful drone strikes on Taliban violence in Pakistan, showing the deterrent effects of drone strikes are quite strong while the incapacitation effects of drone strikes are weak or non-existent.

Our work has relevance for the current US drones policy in Pakistan as well as possible use of the policy in other parts of the world. It also provides empirical evidence of deterrence effects of a specific counter-terrorism policy across different factions of a larger group with a common ideology (the Taliban). We find that these deterrent effects can vary across the different factions, with vengeance effects being stronger for some factions than for others. Insofar as the incapacitation effect of the drone strikes comes from targeted killing of Taliban leaders, we find that such an incapacitation effect (in the sense of reducing Taliban violence) is minimal but that there is some deterrent effect of drone strikes on Taliban violence. Our most important finding is that drone strikes matter, but only for Taliban violence in Pakistan. There is little or no effect of drone strikes on Taliban violence across the border in Afghanistan. 


\section{References}

[1] Granger, C. W. J. (1969), "Investigating Causal Relations by Econometric Models and Cross-Spectral Methods," Econometrica 37(3):324-38. 43(18):2251-2265.

[2] Jaeger, D. A. and M. D. Paserman (2006) "Israel, the Palestinian Factions, and the Cycle of Violence," American Economic Review: Papers and Proceedings 96(2):45-49.

[3] Jaeger, D. A. and M. D. Paserman (2008) "The Cycle of Violence? An Empirical Analysis of Fatalities in the Palestinian-Israeli Conflict," American Economic Review 98(3):1591-1604.

[4] Jaeger, D. A. and M. D. Paserman (2009) "The Shape of Things to Come? Assessing the Effectiveness of Suicide Attacks and Targeted Killings," Quarterly Journal of Political Science, 4(4):315-342.

[5] Newey, W. K and West, K. D. (1987) "A Simple, Positive Semi-definite, Heteroskedasticity and Autocorrelation Consistent Covariance Matrix,"' Econometrica 55 (3): 703708. 
Figure 1: Monthly Patterns in Terrorist Attacks by the Taliban and Drone Strikes, WITS data from January 2005 to December 2010

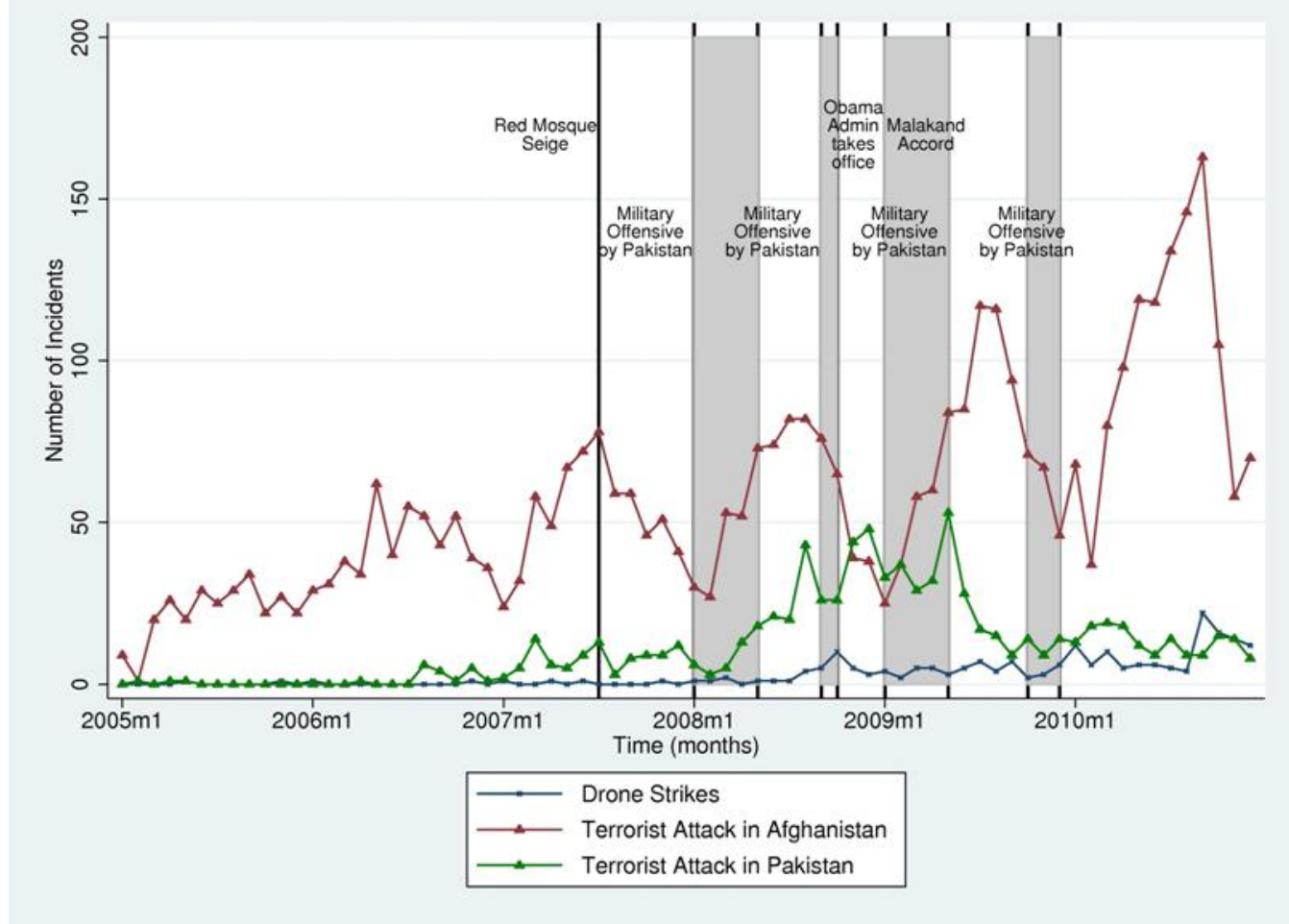

Notes: Drone Strikes data, source: New America Foundation. Terrorist incidents data, source: Worldwide Incidents Tracking System, collected by the National Counterterrorism Center. 
Figure 2: Spatial Patterns in number of Terrorist Attacks by the Taliban and Al-Qaeda in Afghanistan, WITS data from January 2005 to December 2010

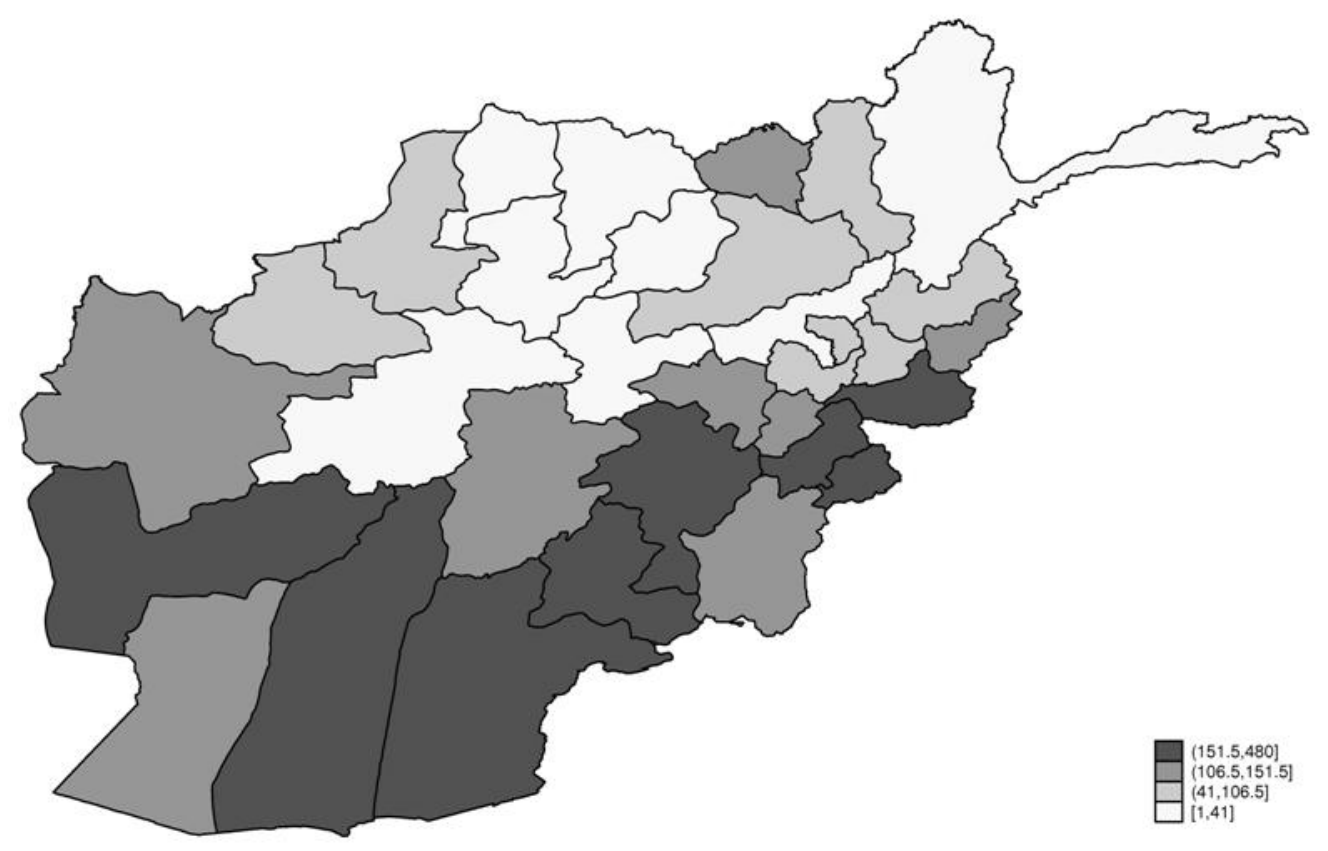

${ }^{1}$ Notes: Terrorist incidents data, source: Worldwide Incidents Tracking System, collected by the National Counterterrorism Center. 
Figure 3: Spatial Patterns in number of Terrorist Attacks by the Taliban and Al-Qaeda in Pakistan, WITS data from January 2005 to December 2010

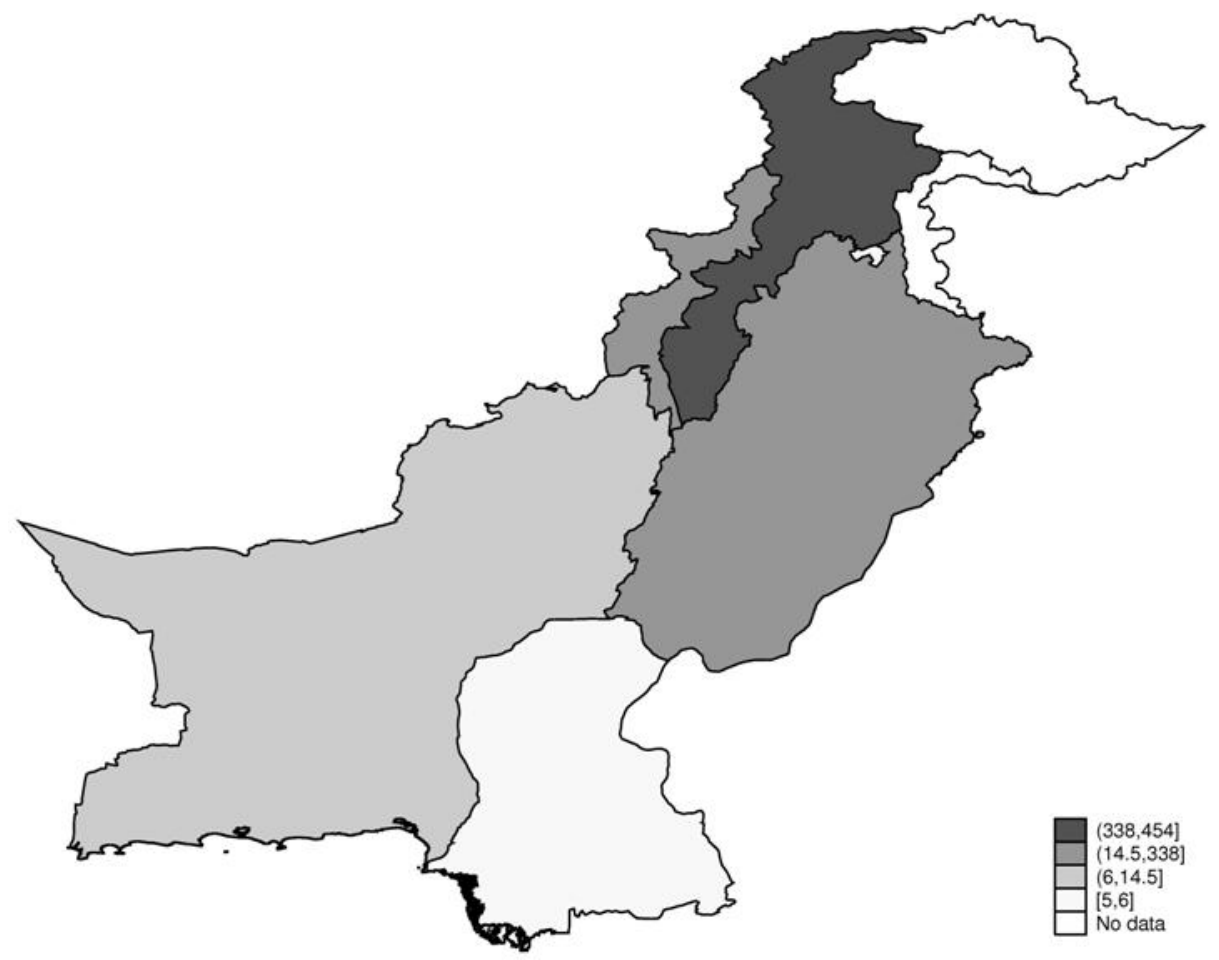

${ }^{1}$ Notes: Terrorist incidents data, source: Worldwide Incidents Tracking System, collected by the National Counterterrorism Center. 
Table 1: Frequency of Drone Strikes by the U.S. and Terrorist Attacks by Taliban and Al-Qaeda

\begin{tabular}{lcccccc}
\hline Year & 2005 & 2006 & 2007 & 2008 & 2009 & 2010 \\
\hline $\begin{array}{l}\text { Number of Drone Strikes } \\
\text { of which }\end{array}$ & 2 & 2 & 4 & 34 & 53 & 118 \\
Successful & 2 & 0 & 0 & 11 & 9 & 14 \\
\hline $\begin{array}{l}\text { Number of Terrorist Attacks in Afghanistan } \\
\text { of which }\end{array}$ & 264 & 511 & 636 & 691 & 860 & 1196 \\
$\begin{array}{l}\text { Lethal Attacks } \\
\text { Suicide Attacks }\end{array}$ & 179 & 292 & 382 & 381 & 460 & 615 \\
\hline $\begin{array}{l}\text { Number of Terrorist Attacks in Pakistan } \\
\text { of which }\end{array}$ & 7 & 46 & 52 & 58 & 55 & 54 \\
$\begin{array}{l}\text { Lethal Attacks } \\
\text { Suicide Attacks }\end{array}$ & 3 & 18 & 95 & 273 & 290 & 158 \\
\hline
\end{tabular}

${ }^{1}$ Drone Strikes data, source: New America Foundation. Terrorist incidents data, source: Worldwide Incidents Tracking System, collected by the National Counterterrorism Center. Terrorist incidents are restricted to those where the perpetrator was identified as Taliban or Al-Qaeda.

${ }^{2}$ Successful drone strike is one in which a militant leader is reported killed.

${ }^{3}$ Lethal Taliban attack is one with at least one reported casualty. 
Table 2: Daily Drone Strike Reaction Functions

\begin{tabular}{|c|c|c|c|c|}
\hline & \multicolumn{2}{|c|}{ Incidence of Strikes } & \multicolumn{2}{|c|}{ Number of Strikes } \\
\hline & Coefficient & SE & Coefficient & $\mathrm{SE}$ \\
\hline \multicolumn{5}{|c|}{ A. Drone Strikes } \\
\hline$t-1$ & -0.040 & $(0.029)$ & -0.006 & $(0.029)$ \\
\hline$t-2$ & 0.010 & $(0.030)$ & 0.001 & $(0.026)$ \\
\hline$t-3$ & -0.015 & $(0.025)$ & -0.041 & $(0.022)$ \\
\hline$t-4$ & 0.000 & $(0.033)$ & 0.035 & $(0.033)$ \\
\hline$t-5$ & 0.016 & $(0.034)$ & 0.034 & $(0.039)$ \\
\hline$t-6$ & 0.032 & $(0.037)$ & 0.026 & $(0.040)$ \\
\hline$t-7$ & 0.022 & $(0.030)$ & 0.056 & $(0.032)$ \\
\hline$t-8$ & -0.010 & $(0.029)$ & -0.018 & $(0.025)$ \\
\hline$t-9$ & -0.028 & $(0.032)$ & -0.018 & $(0.034)$ \\
\hline$t-10$ & $0.070^{* *}$ & $(0.030)$ & $0.062^{*}$ & $(0.029)$ \\
\hline$t-11$ & 0.025 & $(0.036)$ & 0.080 & $(0.055)$ \\
\hline$t-12$ & -0.008 & $(0.030)$ & -0.002 & $(0.024)$ \\
\hline$t-13$ & -0.013 & $(0.030)$ & -0.018 & $(0.027)$ \\
\hline$t-14$ & 0.044 & $(0.031)$ & 0.050 & $(0.034)$ \\
\hline$t-15$ & 0.038 & $(0.034)$ & 0.007 & $(0.040)$ \\
\hline$t-16$ & 0.036 & $(0.038)$ & -0.013 & $(0.037)$ \\
\hline$t-17$ & 0.024 & $(0.029)$ & 0.006 & $(0.027)$ \\
\hline$t-18$ & 0.008 & $(0.035)$ & 0.001 & $(0.032)$ \\
\hline$t-19$ & 0.046 & $(0.028)$ & $0.078^{*}$ & $(0.038)$ \\
\hline$t-20$ & -0.008 & $(0.031)$ & 0.021 & $(0.034)$ \\
\hline$t-21$ & -0.008 & $(0.035)$ & -0.021 & $(0.038)$ \\
\hline \multicolumn{5}{|c|}{ B. Terrorist Attacks by Taliban in Afghanistan } \\
\hline$t-1$ & 0.008 & $(0.018)$ & 0.000 & $(0.003)$ \\
\hline$t-2$ & $-0.047^{*}$ & $(0.023)$ & 0.004 & $(0.004)$ \\
\hline$t-3$ & -0.030 & $(0.024)$ & -0.006 & $(0.003)$ \\
\hline$t-4$ & 0.034 & $(0.021)$ & 0.007 & $(0.007)$ \\
\hline$t-5$ & 0.002 & $(0.020)$ & -0.005 & $(0.004)$ \\
\hline$t-6$ & 0.020 & $(0.022)$ & -0.004 & $(0.003)$ \\
\hline$t-7$ & 0.010 & $(0.022)$ & 0.007 & $(0.004)$ \\
\hline$t-8$ & -0.032 & $(0.023)$ & 0.005 & $(0.007)$ \\
\hline$t-9$ & -0.025 & $(0.024)$ & 0.002 & $(0.004)$ \\
\hline$t-10$ & -0.004 & $(0.021)$ & 0.001 & $(0.005)$ \\
\hline$t-11$ & -0.026 & $(0.021)$ & $-0.007^{*}$ & $(0.003)$ \\
\hline$t-12$ & -0.012 & $(0.021)$ & -0.005 & $(0.003)$ \\
\hline$t-13$ & -0.017 & $(0.024)$ & -0.004 & $(0.004)$ \\
\hline$t-14$ & $0.052^{* *}$ & $(0.022)$ & 0.010 & $(0.006)$ \\
\hline$t-15$ & 0.000 & $(0.021)$ & $-0.010^{* * *}$ & $(0.003)$ \\
\hline$t-16$ & -0.020 & $(0.019)$ & -0.001 & $(0.004)$ \\
\hline$t-17$ & 0.000 & $(0.018)$ & -0.002 & $(0.004)$ \\
\hline$t-18$ & $0.036^{*}$ & $(0.018)$ & $0.013^{* * *}$ & $(0.005)$ \\
\hline$t-19$ & 0.013 & $(0.021)$ & 0.001 & $(0.005)$ \\
\hline$t-20$ & -0.018 & $(0.021)$ & $0.011^{*}$ & $(0.005)$ \\
\hline$t-21$ & 0.004 & $(0.022)$ & -0.005 & $(0.003)$ \\
\hline
\end{tabular}


Table 2: Daily Drone Strike Reaction Functions

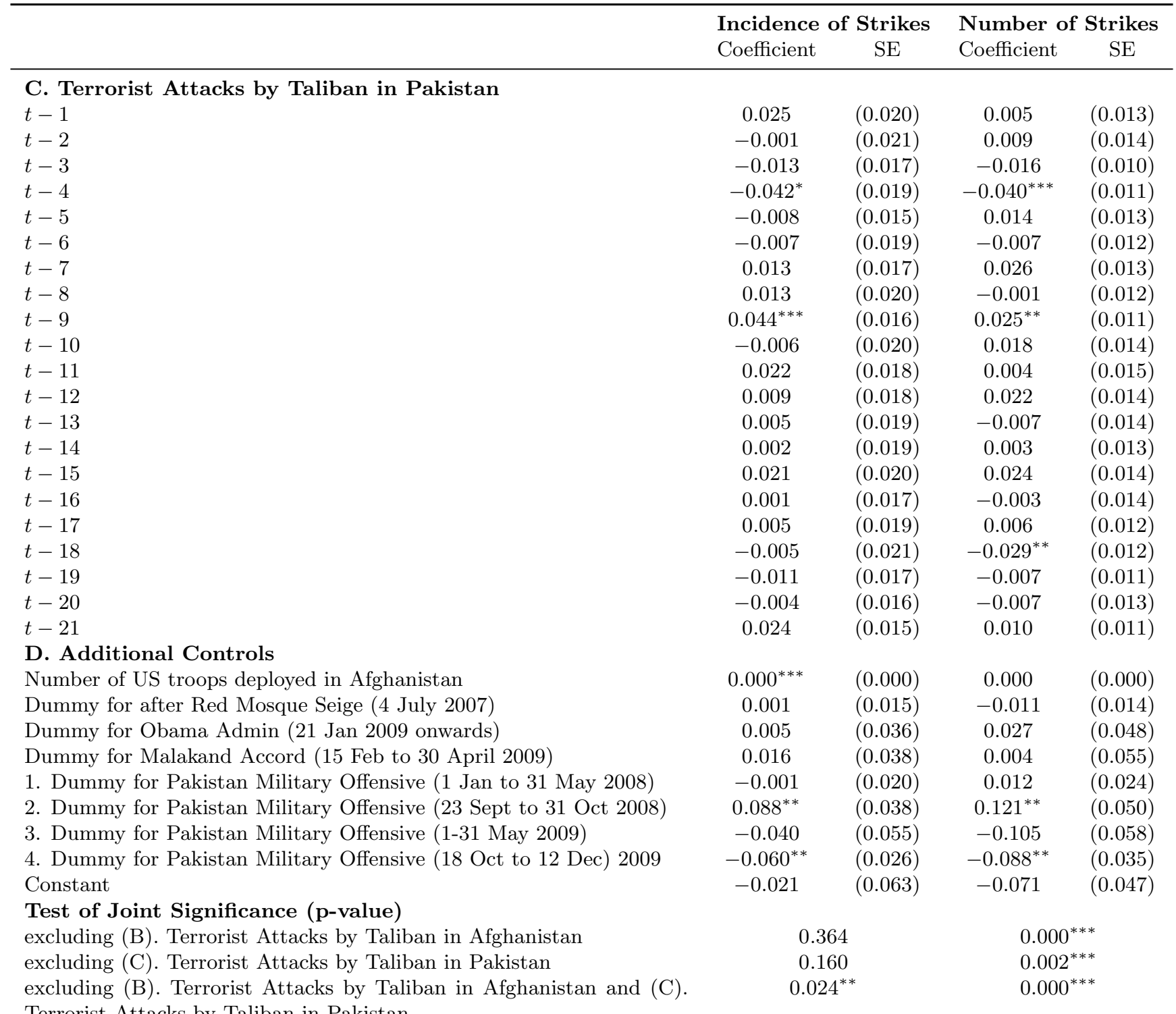

Terrorist Attacks by Taliban in Pakistan

\footnotetext{
${ }^{1}$ Drone Strikes data, source: New America Foundation. Terrorist incidents data, source: Worldwide Incidents Tracking System, collected by the National Counterterrorism Center. Terrorist incidents are restricted to those where the perpetrator was identified as Taliban or Al-Qaeda.

${ }^{2}$ Sample restricted to 1440 days (number of observations) between January 1, 2007 and December 31, 2010.

${ }^{3}$ Regressions include day of week indicators.

${ }^{4}$ Heteroscedasticity/Autocorrelation corrected Newey-West standard errors

$5 *$ significant at the $5 \%$ level, ${ }^{* *}$ significant at the $2.5 \%$ level, ${ }^{* * *}$ significant at the $1 \%$ level.
} 
Table 3: Daily Taliban Reaction Functions in Afghanistan

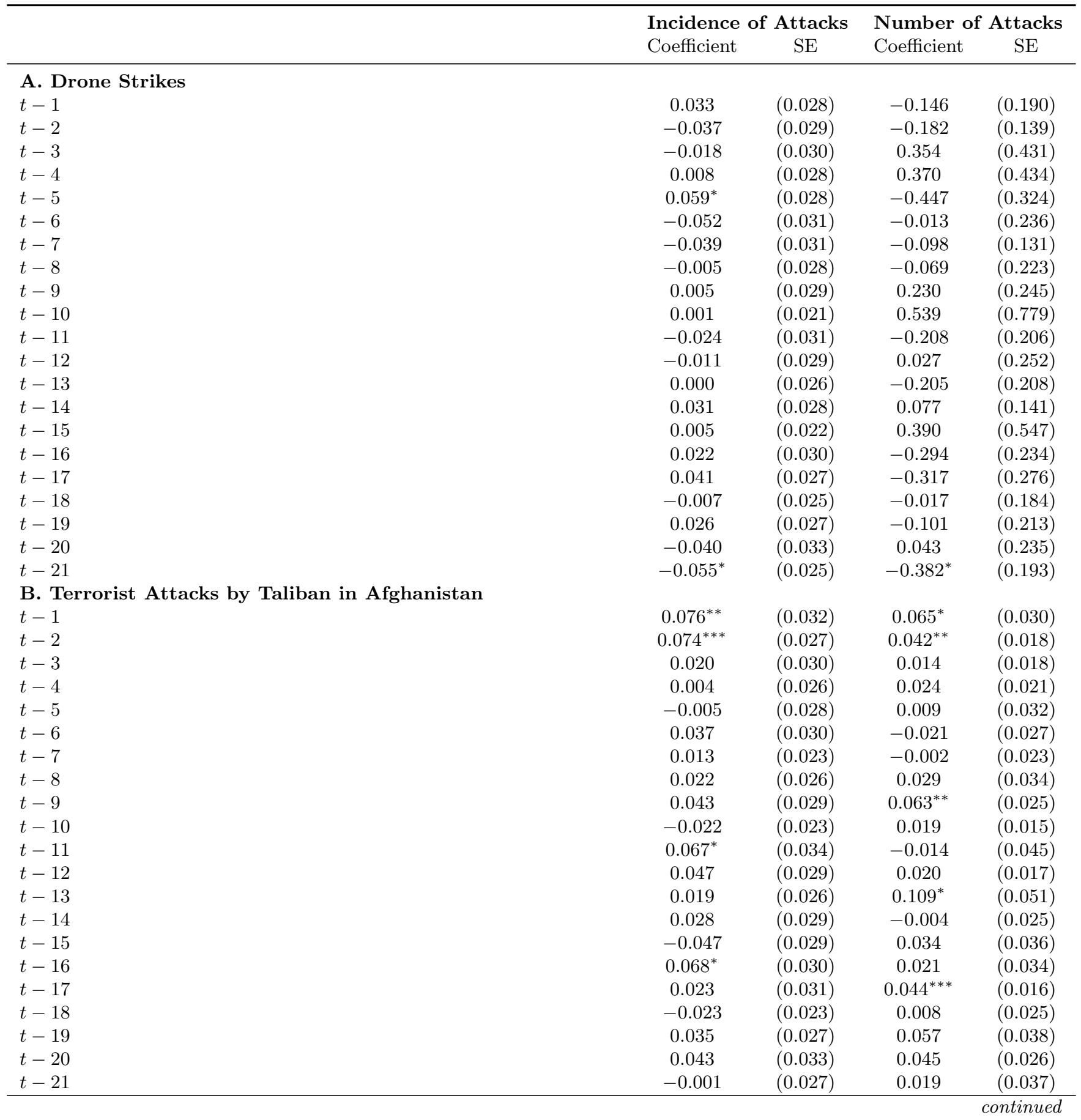


Table 3: Daily Taliban Reaction Functions in Afghanistan



Pakistan

\footnotetext{
${ }^{1}$ Drone Strikes data, source: New America Foundation. Terrorist incidents data, source: Worldwide Incidents Tracking System, collected by the National Counterterrorism Center. Terrorist incidents are restricted to those where the perpetrator was identified as Taliban or Al-Qaeda.

${ }^{2}$ Sample restricted to 1440 days (number of observations) between January 1, 2007 and December 31, 2010.

${ }^{3}$ Regressions include day of week indicators.

${ }^{4}$ Heteroscedasticity/Autocorrelation corrected Newey-West standard errors.

$5 *$ significant at the $5 \%$ level, ${ }^{* *}$ significant at the $2.5 \%$ level, ${ }^{* * *}$ significant at the $1 \%$ level.
} 
Table 4: Daily Taliban Reaction Functions in Pakistan

\begin{tabular}{|c|c|c|c|c|}
\hline & \multicolumn{2}{|c|}{ Incidence of Attacks } & \multicolumn{2}{|c|}{ Number of Attacks } \\
\hline & Coefficient & $\mathrm{SE}$ & Coefficient & $\mathrm{SE}$ \\
\hline \multicolumn{5}{|c|}{ A. Drone Strikes } \\
\hline$t-1$ & 0.080 & $(0.050)$ & 0.065 & $(0.059)$ \\
\hline$t-2$ & -0.048 & $(0.037)$ & $-0.111^{* *}$ & $(0.046)$ \\
\hline$t-3$ & -0.038 & $(0.038)$ & -0.034 & $(0.050)$ \\
\hline$t-4$ & 0.046 & $(0.040)$ & 0.094 & $(0.059)$ \\
\hline$t-5$ & $0.081^{* *}$ & $(0.035)$ & 0.050 & $(0.045)$ \\
\hline$t-6$ & 0.067 & $(0.041)$ & 0.080 & $(0.063)$ \\
\hline$t-7$ & 0.013 & $(0.040)$ & 0.004 & $(0.056)$ \\
\hline$t-8$ & -0.041 & $(0.045)$ & 0.033 & $(0.067)$ \\
\hline$t-9$ & -0.001 & $(0.036)$ & 0.029 & $(0.054)$ \\
\hline$t-10$ & 0.043 & $(0.042)$ & 0.002 & $(0.067)$ \\
\hline$t-11$ & 0.034 & $(0.045)$ & 0.022 & $(0.057)$ \\
\hline$t-12$ & -0.038 & $(0.040)$ & $-0.131^{* * *}$ & $(0.048)$ \\
\hline$t-13$ & $-0.090^{* *}$ & $(0.039)$ & 0.027 & $(0.062)$ \\
\hline$t-14$ & 0.009 & $(0.038)$ & 0.051 & $(0.056)$ \\
\hline$t-15$ & 0.001 & $(0.042)$ & -0.031 & $(0.061)$ \\
\hline$t-16$ & 0.010 & $(0.041)$ & 0.019 & $(0.061)$ \\
\hline$t-17$ & 0.069 & $(0.040)$ & 0.073 & $(0.063)$ \\
\hline$t-18$ & 0.016 & $(0.039)$ & -0.028 & $(0.050)$ \\
\hline$t-19$ & 0.040 & $(0.041)$ & 0.016 & $(0.062)$ \\
\hline$t-20$ & -0.043 & $(0.051)$ & -0.054 & $(0.062)$ \\
\hline$t-21$ & 0.021 & $(0.039)$ & 0.068 & $(0.072)$ \\
\hline \multicolumn{5}{|c|}{ B. Terrorist Attacks by the Taliban in Afghanistan } \\
\hline$t-1$ & -0.021 & $(0.030)$ & 0.004 & $(0.007)$ \\
\hline$t-2$ & -0.024 & $(0.030)$ & -0.003 & $(0.007)$ \\
\hline$t-3$ & -0.016 & $(0.030)$ & 0.008 & $(0.008)$ \\
\hline$t-4$ & 0.043 & $(0.036)$ & -0.005 & $(0.006)$ \\
\hline$t-5$ & -0.028 & $(0.037)$ & -0.008 & $(0.006)$ \\
\hline$t-6$ & -0.017 & $(0.034)$ & 0.003 & $(0.007)$ \\
\hline$t-7$ & -0.061 & $(0.034)$ & $0.015^{* *}$ & $(0.006)$ \\
\hline$t-8$ & 0.038 & $(0.032)$ & -0.001 & $(0.007)$ \\
\hline$t-9$ & -0.026 & $(0.034)$ & -0.004 & $(0.006)$ \\
\hline$t-10$ & 0.004 & $(0.036)$ & -0.004 & $(0.006)$ \\
\hline$t-11$ & 0.023 & $(0.037)$ & -0.004 & $(0.007)$ \\
\hline$t-12$ & 0.026 & $(0.033)$ & -0.002 & $(0.005)$ \\
\hline$t-13$ & -0.031 & $(0.035)$ & -0.005 & $(0.007)$ \\
\hline$t-14$ & -0.010 & $(0.032)$ & 0.000 & $(0.007)$ \\
\hline$t-15$ & -0.013 & $(0.036)$ & 0.023 & $(0.012)$ \\
\hline$t-16$ & $-0.093^{* * *}$ & $(0.033)$ & $-0.022^{* * *}$ & $(0.008)$ \\
\hline$t-17$ & 0.045 & $(0.035)$ & -0.003 & $(0.006)$ \\
\hline$t-18$ & 0.014 & $(0.035)$ & 0.005 & $(0.009)$ \\
\hline$t-19$ & -0.009 & $(0.041)$ & 0.008 & $(0.006)$ \\
\hline$t-20$ & 0.020 & $(0.039)$ & -0.006 & $(0.006)$ \\
\hline$t-21$ & -0.037 & $(0.032)$ & 0.004 & $(0.006)$ \\
\hline
\end{tabular}




\begin{tabular}{|c|c|c|c|c|}
\hline & \multicolumn{2}{|c|}{ Incidence of Attacks } & \multicolumn{2}{|c|}{ Number of Attacks } \\
\hline & Coefficient & $\mathrm{SE}$ & Coefficient & $\mathrm{SE}$ \\
\hline \multicolumn{5}{|l|}{ C. Terrorist Attacks by the Taliban in Pakistan } \\
\hline$t-1$ & $0.123^{* * *}$ & $(0.025)$ & $0.164^{* * *}$ & $(0.037)$ \\
\hline$t-2$ & 0.025 & $(0.027)$ & 0.035 & $(0.027)$ \\
\hline$t-3$ & 0.035 & $(0.024)$ & 0.018 & $(0.029)$ \\
\hline$t-4$ & -0.005 & $(0.028)$ & -0.002 & $(0.028)$ \\
\hline$t-5$ & 0.024 & $(0.029)$ & 0.013 & $(0.034)$ \\
\hline$t-6$ & 0.023 & $(0.027)$ & $0.093^{* *}$ & $(0.037)$ \\
\hline$t-7$ & 0.015 & $(0.025)$ & -0.015 & $(0.042)$ \\
\hline$t-8$ & $0.059^{*}$ & $(0.029)$ & 0.073 & $(0.038)$ \\
\hline$t-9$ & 0.039 & $(0.027)$ & $0.069^{*}$ & $(0.032)$ \\
\hline$t-10$ & -0.039 & $(0.026)$ & -0.016 & $(0.036)$ \\
\hline$t-11$ & 0.024 & $(0.030)$ & $0.073^{*}$ & $(0.033)$ \\
\hline$t-12$ & 0.001 & $(0.027)$ & 0.014 & $(0.036)$ \\
\hline$t-13$ & 0.009 & $(0.028)$ & 0.039 & $(0.031)$ \\
\hline$t-14$ & 0.015 & $(0.031)$ & -0.038 & $(0.031)$ \\
\hline$t-15$ & 0.022 & $(0.027)$ & 0.037 & $(0.027)$ \\
\hline$t-16$ & -0.051 & $(0.026)$ & -0.033 & $(0.031)$ \\
\hline$t-17$ & 0.054 & $(0.027)$ & 0.015 & $(0.027)$ \\
\hline$t-18$ & -0.023 & $(0.027)$ & -0.042 & $(0.031)$ \\
\hline$t-19$ & 0.001 & $(0.026)$ & 0.036 & $(0.035)$ \\
\hline$t-20$ & $0.058^{*}$ & $(0.028)$ & 0.013 & $(0.034)$ \\
\hline$t-21$ & 0.022 & $(0.028)$ & 0.017 & $(0.030)$ \\
\hline \multicolumn{5}{|l|}{ D. Additional Controls } \\
\hline Number of US troops deployed in Afghanistan & 0.000 & $(0.000)$ & 0.000 & $(0.000)$ \\
\hline Dummy for after Red Mosque Seige (4 July 2007) & $0.123^{* * *}$ & $(0.046)$ & $0.228^{* * *}$ & $(0.078)$ \\
\hline Dummy for Obama Admin (21 Jan 2009 onwards) & 0.027 & $(0.056)$ & 0.011 & $(0.114)$ \\
\hline Dummy for Malakand Accord (15 Feb to 30 April 2009) & 0.054 & $(0.048)$ & 0.081 & $(0.114)$ \\
\hline 1. Dummy for Pakistan Military Offensive (1 Jan to 31 May 2008) & $-0.136^{* *}$ & $(0.054)$ & $-0.194^{*}$ & $(0.090)$ \\
\hline 2. Dummy for Pakistan Military Offensive (23 Sept to 31 Oct 2008) & 0.029 & $(0.087)$ & -0.011 & $(0.142)$ \\
\hline 3. Dummy for Pakistan Military Offensive (1-31 May 2009) & $0.190^{* * *}$ & $(0.069)$ & 0.400 & $(0.450)$ \\
\hline 4. Dummy for Pakistan Military Offensive (18 Oct to 12 Dec 2009) & -0.077 & $(0.040)$ & -0.099 & $(0.068)$ \\
\hline Constant & $0.262^{* * *}$ & $(0.077)$ & 0.091 & $(0.076)$ \\
\hline \multicolumn{5}{|l|}{ Test of Joint Significance } \\
\hline excluding (A). Drone Strikes & \multicolumn{2}{|c|}{$0.005^{* * *}$} & \multicolumn{2}{|c|}{$0.002^{* * *}$} \\
\hline excluding (B). Terrorist Attacks by Taliban in Afghanistan & \multicolumn{2}{|c|}{0.055} & \multicolumn{2}{|c|}{$0.000^{* * *}$} \\
\hline excluding (A). Drone Strikes and (B). Terrorist Attacks by Taliban in & \multicolumn{2}{|c|}{$0.000^{* * *}$} & \multicolumn{2}{|c|}{0.085} \\
\hline
\end{tabular}

Afghanistan

\footnotetext{
${ }^{1}$ Drone Strikes data, source: New America Foundation. Terrorist incidents data, source: Worldwide Incidents Tracking System, collected by the National Counterterrorism Center. Terrorist incidents are restricted to those where the perpetrator was identified as Taliban or Al-Qaeda.

${ }^{2}$ Sample restricted to 1440 days (number of observations) between January 1, 2007 and December 31, 2010.

${ }^{3}$ Regressions include day of week indicators.

${ }^{4}$ Heteroscedasticity/Autocorrelation corrected Newey-West standard errors.

$5 *$ significant at the $5 \%$ level, ${ }^{* *}$ significant at the $2.5 \%$ level, ${ }^{* * *}$ significant at the $1 \%$ level.
} 
Table 5: Test of Joint Significance (p-value) for different lag structures

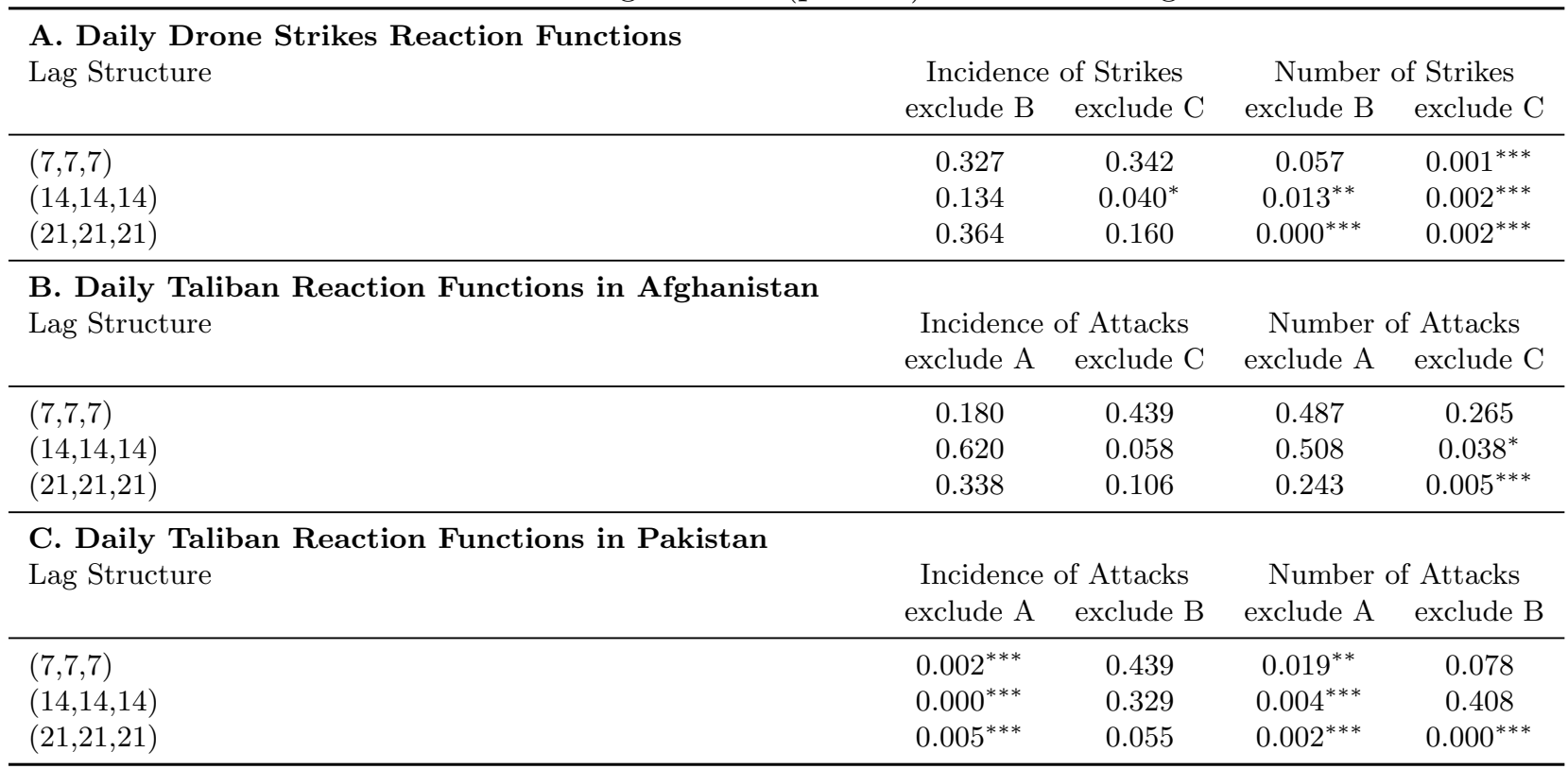

${ }^{1}$ Drone Strikes data, source: New America Foundation. Terrorist incidents data, source: Worldwide Incidents Tracking System, collected by the National Counterterrorism Center. Terrorist incidents are restricted to those where the perpetrator was identified as Taliban or Al-Qaeda. Data is used for the time period January 2007 to December 2010.

2 Tests of joint significance are carried out on OLS regressions of (A) Daily Drone Strikes, (B) Daily Terrorist Attacks in Afghanistan and (C) Daily Terrorist Attacks in Pakistan on lags of Drone Strikes, Terrorist Attacks in Afghanistan and Terrorist Attacks in Pakistan. Regressions are estimated with the given lag length. Each regression includes the controls specified in (D) in tables 2, 3 and 4 as well as day of week indicators. Standard errors are heteroscedasticity/autocorrelation corrected Newey-West standard errors.

$3 *$ significant at the $5 \%$ level, ${ }^{* *}$ significant at the $2.5 \%$ level, ${ }^{* * *}$ significant at the $1 \%$ level. 
Table 6: Test of Joint Significance (p-value) for different Time Aggregations

\begin{tabular}{lcc}
\hline A. Drone Strikes Reaction Functions & & \\
Time Aggregation & $\begin{array}{c}\text { Number of Strikes } \\
\text { exclude B }\end{array}$ & exclude C \\
\hline Daily, 21 lags & $0.000^{* * *}$ & $0.002^{* * *}$ \\
Weekly, 3 lags & 0.524 & 0.485 \\
Monthly, 1 lag & 0.943 & 0.465 \\
\hline B. Taliban Reaction Functions in Afghanistan & & \\
Time Aggregation & Number of Attacks \\
& exclude A & exclude C \\
\hline Daily, 21 lags & 0.243 & $0.005^{* * *}$ \\
Weekly, 3 lags & 0.118 & 0.686 \\
Monthly, 1 lag & $0.000^{* * *}$ & 0.867 \\
\hline C. Taliban Reaction Functions in Pakistan & \multicolumn{3}{c}{} \\
Time Aggregation & Number of Attacks \\
& exclude A & exclude B \\
\hline Daily, 21 lags & $0.002^{* * *}$ & $0.000^{* * *}$ \\
Weekly, 3 lags & 0.426 & 0.329 \\
Monthly, 1 lag & 0.375 & 0.886 \\
\hline
\end{tabular}

${ }^{1}$ Drone Strikes data, source: New America Foundation. Terrorist incidents data, source: Worldwide Incidents Tracking System, collected by the National Counterterrorism Center. Terrorist incidents are restricted to those where the perpetrator was identified as Taliban or Al-Qaeda. Data is used for the time period January 2007 to December 2010.

${ }^{2}$ Tests of joint significance are carried out on OLS regressions of (A) Drone Strikes, (B) Terrorist Attacks in Afghanistan and (C) Terrorist Attacks in Pakistan on lags of Drone Strikes, Terrorist Attacks in Afghanistan and Terrorist Attacks in Pakistan. Regressions are estimated with the given time aggregation (daily, weekly and monthly) and lag length. Each regression includes the controls specified in (D) in tables 2, 3 and 4 as well as day of week/week or month of year indicators. Standard errors are heteroscedasticity/autocorrelation corrected Newey-West standard errors.

$3 *$ significant at the $5 \%$ level, ${ }^{* *}$ significant at the $2.5 \%$ level, ${ }^{* * *}$ significant at the $1 \%$ level. 
Table 7: Test of Joint Significance (p-value) for lethal and suicide attacks by the Taliban

\begin{tabular}{lcccc}
\hline $\begin{array}{l}\text { A. Daily Drone Strikes Reaction Functions } \\
\text { Type of Taliban Attack }\end{array}$ & \multicolumn{2}{c}{$\begin{array}{c}\text { Incidence of Strikes } \\
\text { exclude B }\end{array}$} & \multicolumn{2}{c}{$\begin{array}{c}\text { Number of Strikes } \\
\text { exclude C }\end{array}$} \\
& 0.364 & 0.160 & $0.000^{* * *}$ & $0.002^{* * *}$ \\
\hline All Taliban Attacks & 0.075 & 0.462 & 0.253 & 0.704 \\
Lethal Taliban Attacks & 0.094 & 0.092 & $0.035^{*}$ & 0.305 \\
Suicide Taliban Attacks & & & \\
\hline B. Daily Taliban Reaction Functions in Afghanistan & Incidence of Attacks & Number of Attacks \\
Type of Taliban Attack & exclude A & exclude C & exclude A & exclude C \\
\hline All Taliban Attacks & 0.338 & 0.106 & 0.243 & $0.005^{* * *}$ \\
Lethal Taliban Attacks & 0.078 & 0.396 & 0.662 & $0.006^{* * *}$ \\
Suicide Taliban Attacks & 0.058 & $0.004^{* * *}$ & 0.125 & $0.010^{* *}$ \\
\hline C. Daily Taliban Reaction Functions in Pakistan & \multicolumn{4}{c}{} \\
Type of Taliban Attack & Incidence of Attacks & Number of Attacks \\
& exclude A & exclude B & exclude A & exclude B \\
\hline All Taliban Attacks & $0.005^{* * *}$ & 0.055 & $0.002^{* * *}$ & $0.000^{* * *}$ \\
Lethal Taliban Attacks & $0.031^{*}$ & 0.072 & 0.102 & $0.043^{*}$ \\
Suicide Taliban Attacks & 0.064 & $0.005^{* * *}$ & 0.514 & 0.264 \\
\hline
\end{tabular}

${ }^{1}$ Drone Strikes data, source: New America Foundation. Terrorist incidents data, source: Worldwide Incidents Tracking System, collected by the National Counterterrorism Center. Terrorist incidents are restricted to those where the perpetrator was identified as Taliban or Al-Qaeda. Data is used for the time period January 2007 to December 2010.

${ }^{2}$ Tests of joint significance are carried out on OLS regressions of (A) Daily Drone Strikes, (B) Daily Terrorist Attacks in Afghanistan and (C) Daily Terrorist Attacks in Pakistan on twenty-one lags of Drone Strikes, Terrorist Attacks in Afghanistan and Terrorist Attacks in Pakistan. Regressions are estimated with terrorist attacks restricted to all, lethal or suicide terrorist attacks. Each regression includes the controls specified in (D) in tables 2, 3 and 4 as well as day of week indicators. Standard errors are heteroscedasticity/autocorrelation corrected Newey-West standard errors.

$3 *$ significant at the $5 \%$ level, ${ }^{* *}$ significant at the $2.5 \%$ level, ${ }^{* * *}$ significant at the $1 \%$ level. 
Table 8: Daily Haqqani Reaction Functions, OLS specification

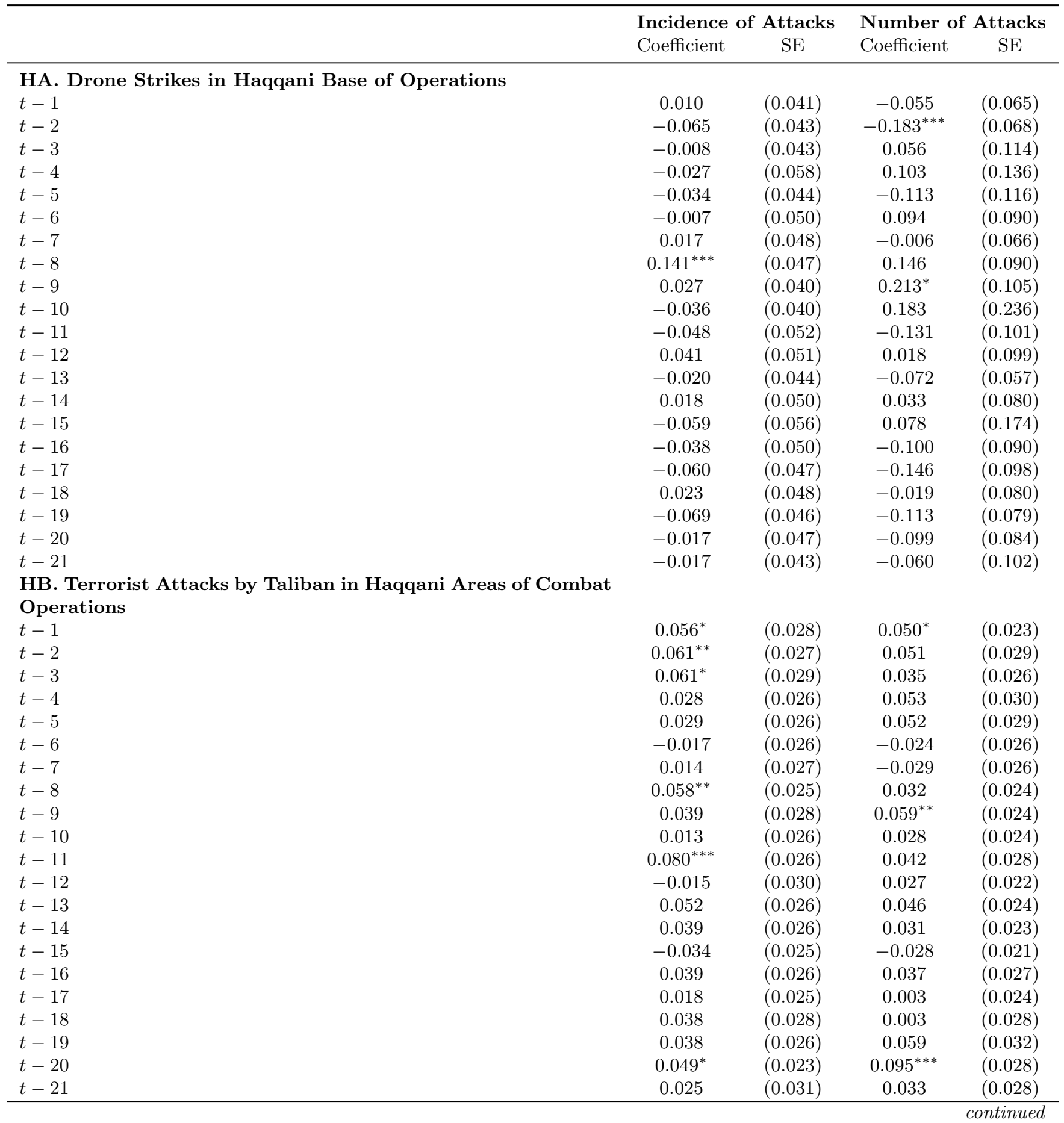


Table 8: Daily Haqqani Reaction Functions, OLS specification

\begin{tabular}{|c|c|c|c|c|}
\hline & \multicolumn{2}{|c|}{ Incidence of Attacks } & \multicolumn{2}{|c|}{ Number of Attacks } \\
\hline & Coefficient & $\mathrm{SE}$ & Coefficient & SE \\
\hline \multicolumn{5}{|l|}{ D. Additional Controls } \\
\hline Number of US troops deployed in Afghanistan & 0.000 & $(0.000)$ & 0.000 & $(0.000)$ \\
\hline Dummy for after Red Mosque Seige (4 July 2007) & -0.013 & $(0.041)$ & -0.020 & $(0.087)$ \\
\hline Dummy for Obama Admin (21 Jan 2009 onwards) & 0.014 & $(0.050)$ & 0.052 & $(0.100)$ \\
\hline Dummy for Malakand Accord (15 Feb to 30 April 2009) & -0.037 & $(0.071)$ & -0.077 & $(0.157)$ \\
\hline 1. Dummy for Pakistan Military Offensive (1 Jan to 31 May 2008) & 0.035 & $(0.055)$ & -0.022 & $(0.113)$ \\
\hline 2. Dummy for Pakistan Military Offensive (23 Sept to 31 Oct 2008) & 0.015 & $(0.052)$ & 0.042 & $(0.096)$ \\
\hline 3. Dummy for Pakistan Military Offensive (1-31 May 2009) & -0.006 & $(0.057)$ & 0.025 & $(0.152)$ \\
\hline 4. Dummy for Pakistan Military Offensive (18 Oct to 12 Dec 2009) & $0.135^{* * *}$ & $(0.044)$ & $0.236^{* * *}$ & $(0.083)$ \\
\hline Constant & $0.138^{* *}$ & $(0.054)$ & $0.298^{* * *}$ & $(0.107)$ \\
\hline $\begin{array}{l}\text { Test of Joint Significance, p-value } \\
\text { excluding (HA). Drone Strikes in Haqqani Base of Operations }\end{array}$ & \multicolumn{2}{|c|}{$0.000^{* * *}$} & \multicolumn{2}{|c|}{$0.002^{* * *}$} \\
\hline
\end{tabular}

\footnotetext{
${ }^{1}$ Drone Strikes data, source: New America Foundation. Terrorist incidents data, source: Worldwide Incidents Tracking System, collected by the National Counterterrorism Center. Terrorist incidents are restricted to those where the perpetrator was identified as Taliban or Al-Qaeda.

${ }^{2}$ Haqqani Base of Operations are taken as areas in North Waziristan, Pakistan. Haqqani Areas of Combat Operations are taken as areas in the states of Khost, Paktia, Paktika, Ghazni, Logar, Wardak, and Kabul (all in Afghanistan).

${ }^{3}$ Sample restricted to 1440 days (number of observations) between January 1, 2007 and December 31, 2010.

${ }^{4}$ Regressions include day of week indicators.

${ }^{5}$ Heteroscedasticity/Autocorrelation corrected Newey-West standard errors.

$6{ }^{*}$ significant at the $5 \%$ level, ${ }^{* *}$ significant at the $2.5 \%$ level, ${ }^{* * *}$ significant at the $1 \%$ level.
} 
Table 9: Daily Mehsud Reaction Functions, OLS specification

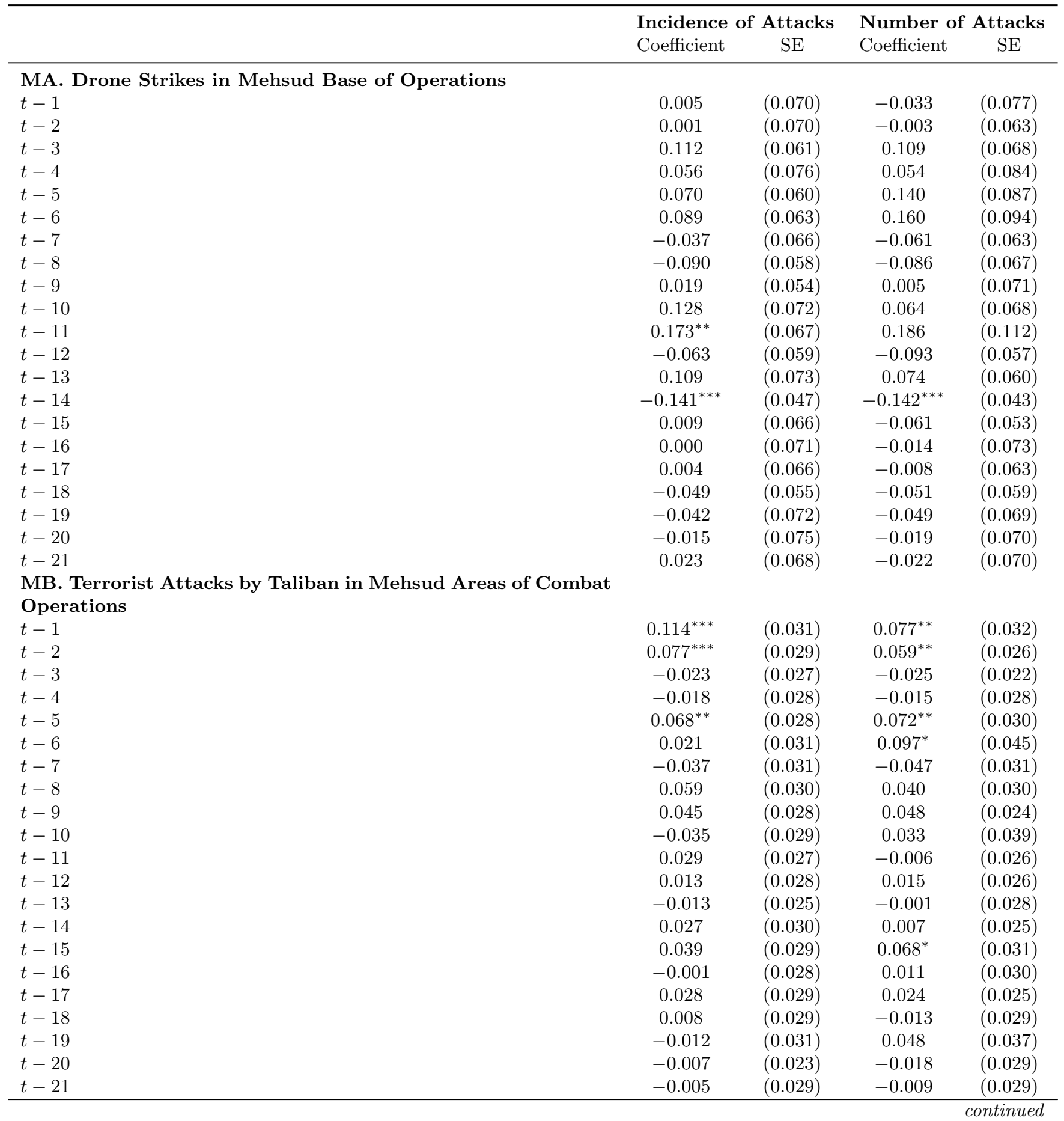


Table 9: Daily Mehsud Reaction Functions, OLS specification

\begin{tabular}{|c|c|c|c|c|}
\hline & \multicolumn{2}{|c|}{ Incidence of Attacks } & \multicolumn{2}{|c|}{ Number of Attacks } \\
\hline & Coefficient & $\mathrm{SE}$ & Coefficient & $\mathrm{SE}$ \\
\hline \multicolumn{5}{|l|}{ D. Additional Controls } \\
\hline Number of US troops deployed in Afghanistan & 0.000 & $(0.000)$ & 0.000 & $(0.000)$ \\
\hline Dummy for after Red Mosque Seige (4 July 2007) & $0.080^{* *}$ & $(0.033)$ & 0.104 & $(0.039)$ \\
\hline Dummy for Obama Admin (21 Jan 2009 onwards) & 0.021 & $(0.053)$ & -0.010 & $(0.066)$ \\
\hline Dummy for Malakand Accord (15 Feb to 30 April 2009) & 0.059 & $(0.063)$ & 0.073 & $(0.080)$ \\
\hline 1. Dummy for Pakistan Military Offensive (1 Jan to 31 May 2008) & -0.051 & $(0.039)$ & -0.060 & $(0.056)$ \\
\hline 2. Dummy for Pakistan Military Offensive (23 Sept to 31 Oct 2008) & -0.035 & $(0.053)$ & -0.063 & $(0.064)$ \\
\hline 3. Dummy for Pakistan Military Offensive (1-31 May 2009) & 0.075 & $(0.085)$ & 0.097 & $(0.088)$ \\
\hline 4. Dummy for Pakistan Military Offensive (18 Oct to 12 Dec 2009) & -0.053 & $(0.027)$ & -0.045 & $(0.043)$ \\
\hline Constant & $0.076^{*}$ & $(0.036)$ & 0.072 & $(0.042)$ \\
\hline $\begin{array}{l}\text { Test of Joint Significance, p-value } \\
\text { excluding (MA). Drone Strikes in Mehsud Base of Operations }\end{array}$ & \multicolumn{2}{|c|}{$0.000^{* * *}$} & \multicolumn{2}{|c|}{$0.000^{* * *}$} \\
\hline
\end{tabular}

\footnotetext{
${ }^{1}$ Drone Strikes data, source: New America Foundation. Terrorist incidents data, source: Worldwide Incidents Tracking System, collected by the National Counterterrorism Center. Terrorist incidents are restricted to those where the perpetrator was identified as Taliban or Al-Qaeda.

${ }^{2}$ Mehsud Base of Operations are taken as areas in South Waziristan, Pakistan. Mehsud Areas of Combat Operations are taken as areas in the Federally Administered Tribal Areas (FATA) in Pakistan.

${ }^{3}$ Sample restricted to 1440 days (number of observations) between January 1, 2007 and December 31, 2010.

${ }^{4}$ Regressions include day of week indicators.

${ }^{5}$ Heteroscedasticity/Autocorrelation corrected Newey-West standard errors.

$6{ }^{*}$ significant at the $5 \%$ level, ${ }^{* *}$ significant at the $2.5 \%$ level, ${ }^{* * *}$ significant at the $1 \%$ level.
} 
Table 10: Daily Taliban Reaction Functions in Afghanistan to Successful/Unsuccessful Drone Strikes, OLS Specification

\begin{tabular}{|c|c|c|c|c|}
\hline & \multicolumn{2}{|c|}{ Incidence of Attacks } & \multicolumn{2}{|c|}{ Number of Attacks } \\
\hline & Coefficient & SE & Coefficient & $\mathrm{SE}$ \\
\hline \multicolumn{5}{|c|}{ A1. Successful Drone Strikes } \\
\hline$t-1$ & -0.002 & $(0.084)$ & -0.456 & $(0.233)$ \\
\hline$t-2$ & 0.023 & $(0.055)$ & 0.131 & $(0.306)$ \\
\hline$t-3$ & -0.004 & $(0.056)$ & -0.165 & $(0.354)$ \\
\hline$t-4$ & $0.081^{*}$ & $(0.040)$ & -0.157 & $(0.248)$ \\
\hline$t-5$ & $0.088^{* * *}$ & $(0.028)$ & 0.051 & $(0.297)$ \\
\hline$t-6$ & -0.024 & $(0.057)$ & 0.029 & $(0.274)$ \\
\hline$t-7$ & -0.074 & $(0.057)$ & 0.139 & $(0.389)$ \\
\hline$t-8$ & -0.073 & $(0.068)$ & 0.429 & $(0.424)$ \\
\hline$t-9$ & -0.037 & $(0.067)$ & 0.189 & $(0.438)$ \\
\hline$t-10$ & -0.031 & $(0.057)$ & -0.505 & $(0.358)$ \\
\hline$t-11$ & -0.029 & $(0.052)$ & -0.317 & $(0.252)$ \\
\hline$t-12$ & -0.028 & $(0.065)$ & -0.322 & $(0.373)$ \\
\hline$t-13$ & -0.114 & $(0.061)$ & $-0.547^{*}$ & $(0.248)$ \\
\hline$t-14$ & 0.036 & $(0.058)$ & 0.231 & $(0.408)$ \\
\hline$t-15$ & 0.088 & $(0.049)$ & 0.307 & $(0.369)$ \\
\hline$t-16$ & 0.060 & $(0.061)$ & -0.054 & $(0.296)$ \\
\hline$t-17$ & 0.026 & $(0.054)$ & 0.001 & $(0.353)$ \\
\hline$t-18$ & 0.048 & $(0.056)$ & 0.378 & $(0.330)$ \\
\hline$t-19$ & 0.001 & $(0.058)$ & -0.071 & $(0.417)$ \\
\hline$t-20$ & 0.026 & $(0.059)$ & 0.238 & $(0.313)$ \\
\hline$t-21$ & -0.110 & $(0.062)$ & -0.056 & $(0.345)$ \\
\hline \multicolumn{5}{|c|}{ A2. Unsuccessful Drone Strikes } \\
\hline$t-1$ & 0.029 & $(0.026)$ & -0.060 & $(0.200)$ \\
\hline$t-2$ & $-0.064^{*}$ & $(0.032)$ & -0.242 & $(0.169)$ \\
\hline$t-3$ & -0.018 & $(0.035)$ & 0.456 & $(0.527)$ \\
\hline$t-4$ & -0.004 & $(0.032)$ & 0.465 & $(0.488)$ \\
\hline$t-5$ & 0.041 & $(0.031)$ & -0.607 & $(0.386)$ \\
\hline$t-6$ & -0.066 & $(0.033)$ & -0.032 & $(0.290)$ \\
\hline$t-7$ & -0.016 & $(0.033)$ & -0.150 & $(0.144)$ \\
\hline$t-8$ & 0.018 & $(0.027)$ & -0.214 & $(0.321)$ \\
\hline$t-9$ & -0.007 & $(0.033)$ & 0.269 & $(0.287)$ \\
\hline$t-10$ & 0.015 & $(0.023)$ & 0.753 & $(0.913)$ \\
\hline$t-11$ & -0.022 & $(0.032)$ & -0.203 & $(0.244)$ \\
\hline$t-12$ & 0.000 & $(0.031)$ & 0.139 & $(0.330)$ \\
\hline$t-13$ & 0.012 & $(0.029)$ & -0.099 & $(0.224)$ \\
\hline$t-14$ & 0.033 & $(0.031)$ & 0.016 & $(0.143)$ \\
\hline$t-15$ & -0.016 & $(0.024)$ & 0.416 & $(0.624)$ \\
\hline$t-16$ & 0.019 & $(0.031)$ & -0.344 & $(0.283)$ \\
\hline$t-17$ & 0.033 & $(0.029)$ & -0.399 & $(0.311)$ \\
\hline$t-18$ & -0.014 & $(0.029)$ & -0.059 & $(0.196)$ \\
\hline$t-19$ & 0.026 & $(0.033)$ & -0.113 & $(0.219)$ \\
\hline$t-20$ & -0.043 & $(0.035)$ & -0.027 & $(0.238)$ \\
\hline$t-21$ & -0.038 & $(0.029)$ & $-0.410^{*}$ & $(0.205)$ \\
\hline \multicolumn{5}{|c|}{ B. Terrorist Attacks by the Taliban in Afghanistan } \\
\hline$t-1$ & $0.074^{* *}$ & $(0.033)$ & 0.064 & $(0.029)$ \\
\hline$t-2$ & $0.073^{* * *}$ & $(0.026)$ & $0.042^{*}$ & $(0.019)$ \\
\hline$t-3$ & 0.021 & $(0.031)$ & 0.011 & $(0.020)$ \\
\hline$t-4$ & 0.005 & $(0.026)$ & 0.028 & $(0.021)$ \\
\hline$t-5$ & -0.003 & $(0.029)$ & 0.013 & $(0.032)$ \\
\hline$t-6$ & 0.040 & $(0.031)$ & -0.022 & $(0.029)$ \\
\hline$t-7$ & 0.018 & $(0.023)$ & -0.002 & $(0.026)$ \\
\hline$t-8$ & 0.026 & $(0.027)$ & 0.030 & $(0.037)$ \\
\hline$t-9$ & 0.041 & $(0.029)$ & $0.054^{* *}$ & $(0.022)$ \\
\hline$t-10$ & -0.023 & $(0.023)$ & 0.027 & $(0.016)$ \\
\hline$t-11$ & 0.061 & $(0.034)$ & -0.011 & $(0.044)$ \\
\hline
\end{tabular}


Table 10: Daily Taliban Reaction Functions in Afghanistan to Successful/Unsuccessful Drone Strikes, OLS Specification

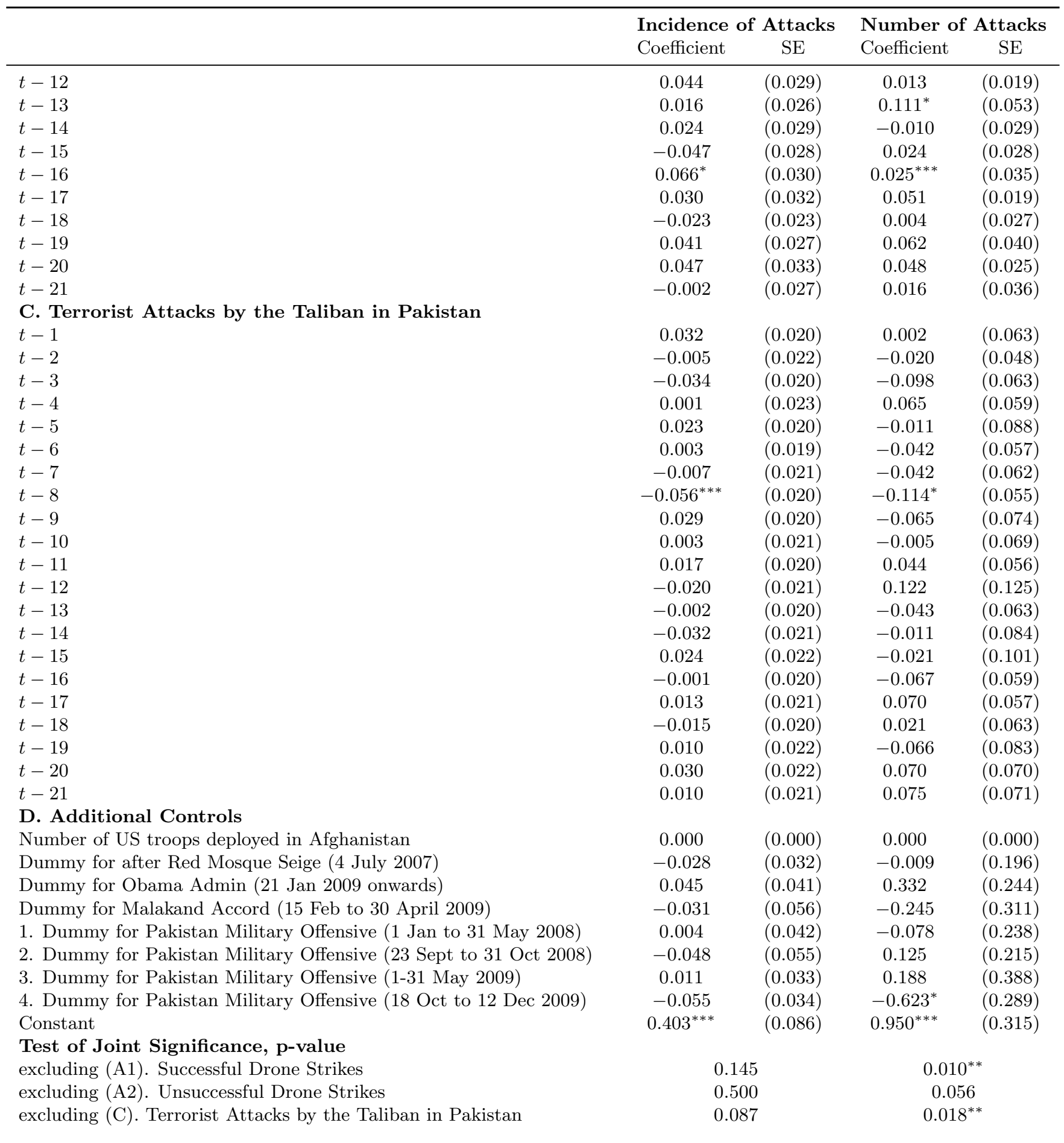

\footnotetext{
${ }^{1}$ Drone Strikes data, source: New America Foundation. Terrorist incidents data, source: Worldwide Incidents Tracking System, collected by the National Counterterrorism Center. Terrorist incidents are restricted to those where the perpetrator was identified as Taliban or Al-Qaeda.

${ }^{2}$ Sample restricted to 1440 days (number of observations) between January 1, 2007 and December 31, 2010.

${ }^{3}$ Regressions include day of week indicators.

${ }^{4}$ Heteroscedasticity/Autocorrelation corrected Newey-West standard errors.

$5{ }^{*}$ significant at the $5 \%$ level, ${ }^{* *}$ significant at the $2.5 \%$ level, ${ }^{* * *}$ significant at the $1 \%$ level.
} 
Table 11: Daily Taliban Reaction Functions in Pakistan to Successful/Unsuccessful Drone Strikes, OLS Specification

\begin{tabular}{|c|c|c|c|c|}
\hline & \multicolumn{2}{|c|}{ Incidence of Attacks } & \multicolumn{2}{|c|}{ Number of Attacks } \\
\hline & Coefficient & SE & Coefficient & $\mathrm{SE}$ \\
\hline \multicolumn{5}{|c|}{ A1. Successful Drone Strikes } \\
\hline$t-1$ & 0.141 & $(0.087)$ & $0.250^{*}$ & $(0.123)$ \\
\hline$t-2$ & 0.027 & $(0.080)$ & -0.124 & $(0.095)$ \\
\hline$t-3$ & $-0.177^{* *}$ & $(0.070)$ & -0.098 & $(0.163)$ \\
\hline$t-4$ & 0.005 & $(0.082)$ & -0.014 & $(0.150)$ \\
\hline$t-5$ & 0.071 & $(0.074)$ & 0.221 & $(0.174)$ \\
\hline$t-6$ & 0.071 & $(0.083)$ & 0.057 & $(0.174)$ \\
\hline$t-7$ & 0.122 & $(0.082)$ & 0.235 & $(0.164)$ \\
\hline$t-8$ & 0.031 & $(0.092)$ & 0.085 & $(0.152)$ \\
\hline$t-9$ & -0.086 & $(0.071)$ & -0.051 & $(0.150)$ \\
\hline$t-10$ & 0.134 & $(0.086)$ & 0.264 & $(0.140)$ \\
\hline$t-11$ & -0.065 & $(0.081)$ & 0.154 & $(0.195)$ \\
\hline$t-12$ & 0.131 & $(0.085)$ & 0.008 & $(0.125)$ \\
\hline$t-13$ & 0.084 & $(0.082)$ & 0.246 & $(0.179)$ \\
\hline$t-14$ & -0.106 & $(0.072)$ & -0.255 & $(0.133)$ \\
\hline$t-15$ & 0.111 & $(0.080)$ & 0.065 & $(0.137)$ \\
\hline$t-16$ & 0.050 & $(0.077)$ & 0.223 & $(0.197)$ \\
\hline$t-17$ & 0.093 & $(0.083)$ & -0.018 & $(0.144)$ \\
\hline$t-18$ & 0.083 & $(0.098)$ & -0.017 & $(0.184)$ \\
\hline$t-19$ & -0.018 & $(0.098)$ & -0.159 & $(0.150)$ \\
\hline$t-20$ & 0.047 & $(0.098)$ & 0.121 & $(0.174)$ \\
\hline$t-21$ & 0.145 & $(0.082)$ & 0.268 & $(0.176)$ \\
\hline \multicolumn{5}{|c|}{ A2. Unsuccessful Drone Strikes } \\
\hline$t-1$ & 0.065 & $(0.049)$ & 0.031 & $(0.064)$ \\
\hline$t-2$ & -0.045 & $(0.042)$ & $-0.103^{*}$ & $(0.053)$ \\
\hline$t-3$ & 0.001 & $(0.043)$ & -0.010 & $(0.056)$ \\
\hline$t-4$ & 0.051 & $(0.045)$ & 0.113 & $(0.067)$ \\
\hline$t-5$ & $0.085^{*}$ & $(0.042)$ & 0.041 & $(0.051)$ \\
\hline$t-6$ & 0.058 & $(0.047)$ & 0.088 & $(0.060)$ \\
\hline$t-7$ & -0.010 & $(0.040)$ & -0.036 & $(0.054)$ \\
\hline$t-8$ & -0.042 & $(0.045)$ & 0.034 & $(0.071)$ \\
\hline$t-9$ & 0.031 & $(0.042)$ & 0.050 & $(0.061)$ \\
\hline$t-10$ & 0.026 & $(0.046)$ & -0.052 & $(0.075)$ \\
\hline$t-11$ & 0.062 & $(0.046)$ & 0.014 & $(0.052)$ \\
\hline$t-12$ & -0.083 & $(0.043)$ & $-0.153^{* * *}$ & $(0.050)$ \\
\hline$t-13$ & $-0.130^{* * *}$ & $(0.041)$ & -0.010 & $(0.062)$ \\
\hline$t-14$ & 0.051 & $(0.045)$ & 0.110 & $(0.066)$ \\
\hline$t-15$ & -0.031 & $(0.046)$ & -0.044 & $(0.065)$ \\
\hline$t-16$ & 0.007 & $(0.045)$ & 0.000 & $(0.062)$ \\
\hline$t-17$ & 0.063 & $(0.048)$ & 0.120 & $(0.071)$ \\
\hline$t-18$ & -0.002 & $(0.043)$ & -0.036 & $(0.056)$ \\
\hline$t-19$ & 0.051 & $(0.043)$ & 0.035 & $(0.068)$ \\
\hline$t-20$ & -0.070 & $(0.058)$ & -0.087 & $(0.065)$ \\
\hline$t-21$ & -0.024 & $(0.042)$ & 0.034 & $(0.085)$ \\
\hline \multicolumn{5}{|c|}{ B. Terrorist Attacks by the Taliban in Afghanistan } \\
\hline$t-1$ & -0.024 & $(0.030)$ & 0.005 & $(0.007)$ \\
\hline$t-2$ & -0.024 & $(0.030)$ & -0.004 & $(0.008)$ \\
\hline$t-3$ & -0.017 & $(0.031)$ & 0.008 & $(0.007)$ \\
\hline$t-4$ & 0.046 & $(0.035)$ & -0.006 & $(0.006)$ \\
\hline$t-5$ & -0.021 & $(0.038)$ & -0.008 & $(0.006)$ \\
\hline$t-6$ & -0.023 & $(0.033)$ & 0.005 & $(0.007)$ \\
\hline$t-7$ & -0.059 & $(0.034)$ & $0.014^{*}$ & $(0.007)$ \\
\hline$t-8$ & 0.037 & $(0.032)$ & -0.003 & $(0.008)$ \\
\hline$t-9$ & -0.022 & $(0.034)$ & -0.002 & $(0.006)$ \\
\hline$t-10$ & 0.007 & $(0.036)$ & -0.001 & $(0.006)$ \\
\hline$t-11$ & 0.018 & $(0.037)$ & -0.002 & $(0.007)$ \\
\hline
\end{tabular}


Table 11: Daily Taliban Reaction Functions in Pakistan to Successful/Unsuccessful Drone Strikes, OLS Specification

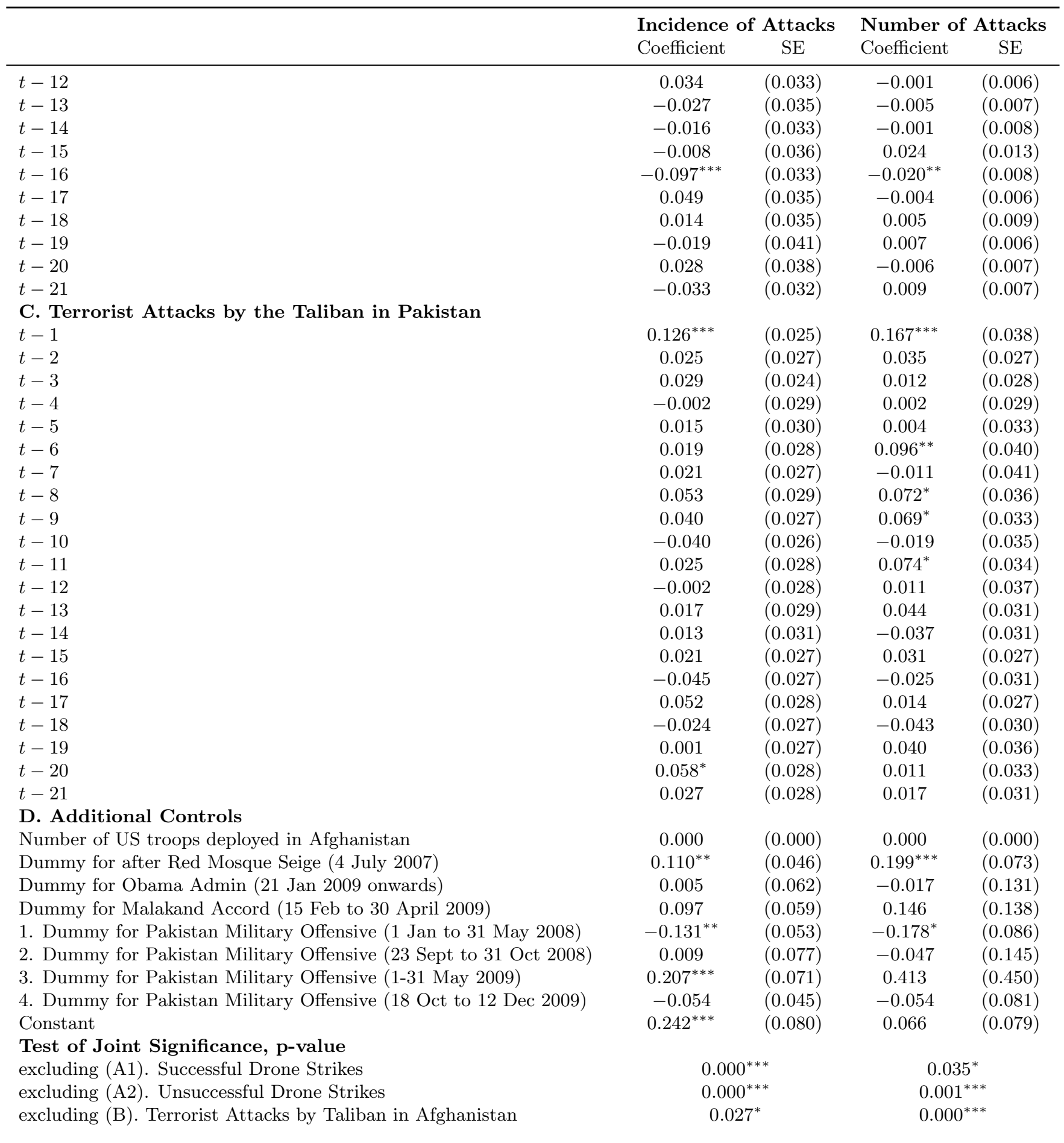

\footnotetext{
${ }^{1}$ Drone Strikes data, source: New America Foundation. Terrorist incidents data, source: Worldwide Incidents Tracking System, collected by the National Counterterrorism Center. Terrorist incidents are restricted to those where the perpetrator was identified as Taliban or Al-Qaeda.

${ }^{2}$ Sample restricted to 1440 days (number of observations) between January 1, 2007 and December 31, 2010.

${ }^{3}$ Regressions include day of week indicators.

${ }^{4}$ Heteroscedasticity/Autocorrelation corrected Newey-West standard errors.

$5{ }^{*}$ significant at the $5 \%$ level, ${ }^{* *}$ significant at the $2.5 \%$ level, ${ }^{* * *}$ significant at the $1 \%$ level.
} 